\title{
Análise global da expressão de RNAs não codificadores no sistema imunológico humano na senescência e sepse
}

\author{
Dissertação de Mestrado \\ apresentada ao Programa Interunidades de Pós-graduação em Bioinformática da \\ Universidade de São Paulo
}

Aluno: Diogo Vieira da Silva Pellegrina

Orientador: Prof. Dr. Eduardo Moraes Rego Reis (Instituto de Química, USP)

Co-orientador: Fabiano Pinheiro da Silva (Faculdade de Medicina da USP)

São Paulo, Junho 2016 


\section{Índice}

$\begin{array}{ll}\text { Resumo } & 2\end{array}$

$\begin{array}{ll}\text { Abstract } & 3\end{array}$

$\begin{array}{ll}\text { Introdução } & 4\end{array}$

Sepse e envelhecimento 4

Transcriptoma 5

Análise do transcriptoma utilizando microarranjos de DNA 6

$\begin{array}{ll}\text { RNAs não codificadores e sistema imune } & 7\end{array}$

Atribuição de função à IncRNAs através de redes de coexpressão.

Busca por IncRNAs usando análise de redes formadas por WGCNA 8

$\begin{array}{ll}\text { Objetivos } & 10\end{array}$

$\begin{array}{ll}\text { Metodologia e Resultados } & 10\end{array}$

$\begin{array}{ll}\text { Amostras de RNA de neutrófilos } & 10\end{array}$

$\begin{array}{ll}\text { Experimentos de expressão gênica } & 11\end{array}$

Análise dos dados de expressão gênica 11

Normalização e filtragem dos dados.

Análises não supervisionadas dos dados de expressão gênica 12

Análise Estatística dos dados de expressão gênica 14

Reanotação do microarranjo para análise de IncRNAs 16

$\begin{array}{ll}\text { Resultados } & 20\end{array}$

Análise de vias moleculares alteradas na sepse $\quad 20$

Validação por q-PCR 25

Construção de redes de coexpresão usando WGCNA 26

Visualização de IncRNAs no Genome Browser 31

Conclusões

Contribuições para o entendimento da senescência na sepse 34

Contribuições para a anotação de IncRNAs envolvidos na sepse 34

Publicações geradas por este trabalho 35

Referências 


\section{Agradecimentos}

Agradecimento à FAPESP:

O aluno foi integralmente financiado com o apoio da Fundação de Amparo à Pesquisa do Estado de São Paulo (FAPESP), processo de no 2014/03150-6. 


\section{Resumo}

A sepse é uma das maiores causas de mortalidade em pacientes hospitalizados, e uma complicação comum, tanto em pacientes clínicos quanto de cirurgias, admitidos em hospitais por causas não infecciosas. A sepse é especialmente comum em pacientes mais velhos, sendo portanto esperado que sua incidência aumente com o envelhecimento da população, e apesar da sua maior taxa de mortalidade, a resposta imune em idosos durante o choque séptico é muito similar à dos pacientes mais jovens. O objetivo desse estudo foi de conduzir uma análise de expressão gênica dos neutrófilos da circulação, tanto de pacientes adultos como de pacientes idosos, observando tanto os mRNAs e as vias em que estão envolvidos, como o papel dos ncRNAs, para um melhor entendimento da resposta imune do indivíduo idoso a infecções severas. Os RNAs de 24 indivíduos, divididos igualmente entre idosos e adultos, e entre pacientes em choque séptico e controles, foram hibridizadas em microarranjos de DNA. Deste experimento foram encontrados genes cuja expressão pode ser utilizada para diferenciar a resposta imune entre adultos e idosos. Estes genes foram observados concentrados em algumas vias, entre elas fosforilação oxidativa, disfunção mitocondrial, sinalização do TGF- $\beta$, entre outras. Além da análise usando os mRNAs, esse trabalho mostra fortes indicações de interações de mRNAs com RNAs não codificadores longos, dos quais a maioria não têm função conhecida. Para propor uma função aos RNAs não codificadores foi construída uma rede de coexpressão em que alguns RNAs de função desconhecida se mostraram fortemente ligados à genes das vias moleculares do ribossomo e da mitocôndria. Também foi observado que para os idosos a rede de coexpressão é menos centralizada, suportando a hipótese de que alterar a expressão de alguns genes chave pode ser o fator determinante para alterar a expressão gênica e um conjunto maior.

Palavras chave: Bioinformática, transcriptoma, microarranjo, WGCNA, envelhecimento, IncRNAs. 


\section{Abstract}

Sepsis is one of the major causes of mortality in hospitalized patients, and a common complication, both in clinical patients and in surgeries, admitted to hospital for non-infectious causes. Sepsis is especially common in older patients, and is therefore expected that its incidence increases as the population ages, and despite its higher mortality rate, the immune response in the elderly during septic shock is very similar to that of younger patients. The objective of this study was to conduct a gene expression analysis of circulating neutrophils, both adults and elderly patients, noting both the mRNAs, the pathways in which those are involved, and the role of ncRNAs, for a better understanding of the immune response of the elderly to severe infections. The RNAs of 24 individuals, equally divided among the adults and the elderly, and among patients in septic shock and controls, were hybridized to DNA microarrays. From this experiment many genes whose expression can be used to differentiate the immune response in adults and the elderly were found. These genes were concentrated in some metabolic pathways, including oxidative phosphorylation, mitochondrial dysfunction, TGF- $\beta$ signaling, and others. Besides the analysis using mRNAs, this work shows strong indications of mRNAs interactions with non coding RNAs, most of which have no known function. To propose a role for noncoding RNAs a coexpression network was built in which some RNAs of unknown function showed strongly connected to genes of the molecular pathways of the ribosome and mitochondria. It was also noted that for the elderly, the coexpression network is less centralized, supporting the hypothesis that altering the expression of a few key genes can be a determining factor for altering the gene expression of a larger set.

Keywords: Bioinformatics, trancriptome, microarray, WGCNA, ageing, lncRNAs. 


\section{Introdução}

\section{Sepse e envelhecimento}

Sepse é uma síndrome complexa desencadeada por infecção e caracterizada por desregulação massiva das redes imunológicas (Iskander, Osuchowski et al. 2013). Pacientes sépticos tem idade média de aproximadamente 65 anos (De Gaudio, Rinaldi et al. 2009) e a incidência de sepse assim como seu risco de mortalidade aumentam significativamente com a idade (Opal, Girard et al. 2005; Heppner, Cornel et al. 2013). Fatores que podem contribuir incluem falhas na integridade de barreiras epiteliais, nos reflexos de tosse e vômito, níveis alterados de consciência, imobilidade, condições médicas concomitantes, dependência de intervenções médicas invasivas, diminutas reservas fisiológicas, deficiências endócrinas e má nutrição (Girard, Opal et al. 2005; Nasa, Juneja et al. 2012).

Problemas na imunidade dos idosos podem ser observados por falhas no sistema imune adaptativo, tanto nas células responsáveis pela imunidade humoral quanto na imunidade mediada por células (Grubeck-Loebenstein and Wick 2002). O envelhecimento da imunidade adaptativa é associado a uma maior resposta do tipo 1 , em que o Interferon-gama (IFN-ү) sinaliza pela ativação de linfócitos T citotóxicos, em detrimento de uma resposta do tipo 2 , em que diversas interleucinas estimulam linfócitos B e eosinófilos a atacarem parasitas extracelulares como helmintos (Mascarucci, Taub et al. 2001; Plackett, Schilling et al. 2003). Em acordo com estas observações foi observada uma maior quantidade de linfócitos $T$ citotóxicos, que atacam células do organismo em que são detectados parasitas intracelulares, em detrimento de outros tipos (Opal, Girard et al. 2005), e também com uma diminuição gradual do número de Linfócitos $B$ e plasmócitos com a idade, enquanto os níveis de imunoglobulinas aumentam (Weksler, Goodhardt et al. 2002).

Pensava-se que a imunidade inata fosse mantida bem conservada em idosos (Shinkai, Konishi et al. 1998), mas estudos recentes apontaram alterações significativas nestes componentes (Opal, Girard et al. 2005). Tais estudos sugerem que alterações de expressão e função de receptores do tipo Toll (TLRs) em função do envelhecimento afetam a resposta do hospedeiro a patogênicos (Renshaw, Rockwell et al. 2002). Níveis 
elevados de inflamação basal (Howcroft, Campisi et al. 2013), ativação anômala de proteínas quinases ativadas por mitógenos (MAP quinase) (Boehmer, Goral et al. 2004), número elevado de células apoptóticas (Plackett, Boehmer et al. 2004), defeitos de fagocitose, geração de espécies reativas de oxigênio e comprometimento da expressão de moléculas co-estimuladoras foram também registrados (Franceschi, Bonafe et al. 2000). Novas evidências indicam que adultos mais velhos apresentam elevados níveis de citosinas pró-inflamatórias, fatores coagulantes do sangue e reagentes de fase aguda em estado estacionário (Fagiolo, Cossarizza et al. 1993; Mari, Mannucci et al. 1995; Cevenini, Monti et al. 2013). Os neutrófilos são mediadores essenciais da resposta imune inata e constituem a primeira linha de defesa contra infecções bacterianas. Em pacientes com sepse se observa uma intensa reprogramação da função dos neutrófilos, que afetam o recrutamento dessas células para sítios de infecção e suas atividades antimicrobianas (Kovach and Standiford 2012). Um trabalho recente demonstrou a redução da quimiotaxia dos neutrófilos para sítios de infecção em pacientes idosos (Brubaker, Rendon et al. 2013), mas associação entre este fenômeno e a susceptibilidade à sepse nestes pacientes ainda é desconhecida.

Alterações na resposta inflamatória dos idosos após uma infecção, no entanto, continua sob debate. Estudos com animais mostraram que mortalidade, inflamação, hipotermia, apoptose e coagulação intravascular disseminada aumentam em animais envelhecidos submetidos a modelos de sepse (Starr and Saito 2014). É intrigante que, apesar dos aspectos bem caracterizados da imunossenescência e da resposta inflamatória exagerada detectada em roedores sépticos e idosos (Tateda, Matsumoto et al. 1996; Turnbull, Wlzorek et al. 2003), estudos clínicos (inclusive advindos do grupo do Dr. Fabiano Pinheiro, co-supervisor deste estudo) tenham encontrado um perfil imunológico semelhante quando comparando pacientes sépticos críticos idosos e adultos (Kelly, MacRedmond et al. 2009; Kale, Yende et al. 2010; Kale and Yende 2011; Pinheiro da Silva, Zampieri et al. 2013).

\section{Transcriptoma}

Embora o DNA contenha toda a informação genética do indivíduo, apenas uma fração dos genes são transcritos em RNA em cada tipo celular, cuja composição e níveis 
relativos podem variar de acordo com estado fisiológico ou patológico. Para inferir sobre a presença de proteínas e a ativação de vias moleculares a qual elas pertencem pode-se fazer um estudo dos RNAs mensageiros (mRNAs) produzidos nas células em estudo. $\mathrm{O}$ transcriptoma é o conjunto de RNAs transcritos a partir de um genoma sob investigação (Franceschi, Bonafe et al. 2000).

Diversas análises de transcriptômica tem revelado que além de mRNAs, os genomas eucarióticos transcrevem diversas famílias de RNAs não codificadores (ncRNAs) que agem de forma regulatória na expressão gênica (Fagiolo, Cossarizza et al. 1993). Algumas classes de ncRNAs como os microRNAs já foram estudadas em detalhe. Os microRNAs maduros possuem cerca de 20 nucleotídeos e estão envolvidos no silenciamento da expressão gênica. Se houver pareamento suficiente entre um miRNA e outro RNA, será formada uma dupla fita que ativa o complexo RISC que cliva o mRNA, inibindo a tradução e resultando na diminuição da expressão gênica, além de servir como um obstáculo para o funcionamento do ribossomo, também inibindo a tradução. É possível portanto prever com razoável confiança quais RNAs um miRNA deve silenciar (Yue, Liu et al. 2009).

Os genomas eucarióticos também transcrevem uma grande variedade de RNAs não codificadores longos (IncRNAs). Os IncRNAs são uma classe bastante heterogênea, sendo que estes podem ter funções distintas e atuar por diferentes vias, agindo tanto por pareamento de bases, ligando-se ao DNA ou a outros RNAs, quanto pela sua estrutura secundária que o confere uma conformação espacial que o permite interagir com proteínas por meio de forças fracas. Uma definição operacional de IncRNAs é que estes são RNAs não codificadores que possuem mais de 200 nucleotídeos. Os IncRNA foram menos caracterizados funcionalmente, mas sabe-se que podem afetar o comportamento da célula em seus diferentes estágios de vida, controlando processos biológicos essenciais como diferenciação, ciclo celular, entre outros (Fatica and Bozzoni 2014).

\section{Análise do transcriptoma utilizando microarranjos de DNA}

Um dos métodos utilizados para determinar o transcriptoma de uma amostra de células ou tecido envolve a técnica de hibridização com microarranjos de DNA. Resumidamente, o RNA é isolado da amostra e utilizado para gerar alvos fluorescentes que a seguir são incubados com uma lâmina de vidro contendo sondas de DNA fita 
simples. Em geral são utilizados microarranjos ordenados e contendo dezenas de milhares de sondas com sequências diferentes de modo a mapear a maior extensão possível do transcriptoma de uma espécie, geralmente espécies modelo. Durante a incubação ocorre o pareamento específico entre alvos e sondas se houver complementaridade das sequencias de ácidos nucleicos. Após lavagem para remoção dos alvos não ligados, a quantidade de alvos hibridizados em cada sonda é determinada utilizando um leitor de lâminas que incide luz no comprimento de onda de excitação de cada fluoróforo e detecta a luz emitida. A partir da intensidade associada a cada sonda pode-se inferir a abundância relativa do RNA correspondente na amostra (Franceschi, Bonafe et al. 2000). Um desenho experimental frequentemente utilizado envolve o uso de dois marcadores fluorescentes, que se distinguem pelo comprimento de onda da luz emitida. Ao marcar duas amostras diferentes com cada um dos marcadores e hibridizalas simultaneamente em um mesmo microarranjo, pode-se aumentar significativamente a precisão com que se compara expressão de RNA das amostras (Peixoto, Vencio et al. 2006).

\section{RNAs não codificadores e sistema imune}

Existem diversas evidências na literatura de que ncRNAs participam de forma direta ou indireta na regulação de respostas imunológicas. Pode-se tomar como exemplo os linfócitos T CD4+, que se diferenciam em subtipos Th1, Th2, Th17, e T regulador. Estes subtipos são definidos pela expressão de citosinas e receptores, e podem ser modificadas de acordo com o ambiente no qual a célula está inserida, de forma a se adaptar conforme necessário. Observou-se que ncRNAs estão envolvidos nestas modificações (Pagani, Rossetti et al. 2013).

Em um outro trabalho envolvendo linfócitos $T$ de camundongos, verificou-se a influência do IncRNA NeST (nettoie Salmonella pas Theiler's,elimina a Salmonela não Theiler), que leva uma maior susceptibilidade à doença de Theiler, mas em contrapartida combate a bactéria salmonela. A regulação deste IncRNA foi estudada detalhadamente em 2013 (Gomez, Wapinski et al. 2013). Em outro trabalho, usando RNA extraído de pulmões de camundongos com SARAS-CoV (severe acute respiratory syndrome 
coronavirus), observou-se 500 IncRNAs diferencialmente expressos (Peng, Gralinski et al. 2010).

Ainda não existem trabalhos que tenham investigado mudanças na expressão de IncRNAs e microRNAs no sistema imunológico humano durante envelhecimento, e um possível papel dessas moléculas na predisposição à sepse. Além disso, nenhum trabalho investigou o papel destes RNAs no curso da sepse, doença que é a principal causa de óbito em Unidades de Terapia Intensiva. Pretendemos neste projeto analisar dados da expressão de mRNAs codificadores de proteína, assim como de RNAs não codificadores, medidos em neutrófilos de indivíduos adultos e idosos, com ou sem sepse, utilizando microarranjos de DNA. Espera-se contribuir com novas informações sobre as alterações moleculares que ocorrem no sistema imune durante a senescência e na infecção generalizada.

\section{Atribuição de função à IncRNAs através de redes de coexpressão.}

Embora novas evidências venham se acumulando à respeito da função de diferentes IncRNAs, esse número é muito pequeno, sendo que a função da maioria dos IncRNAs permanece desconhecida. A bioinformática pode oferecer grande ajuda no processo de anotar a função dos IncRNAs ainda desconhecidos, selecionando candidatos mais prováveis de regularem um determinado processo biológico.

Recolhendo dados de transcriptoma em duas diferentes condições é possível observar como a expressão dos genes responde às variações no ambiente em que estão inseridos. Acredita-se que os IncRNAs possuam papel regulatório na expressão de genes codificadores, ou seja, que a expressão de certos mRNAs é correlacionada à de IncRNAs por meio de interações moleculares.

Uma rede de correlação é uma forma abrangente com que se pode observar o comportamento do transcriptoma frente a uma certa condição experimental. Em uma rede, os genes formam nós em um grafo não orientado em que as ligações são determinadas pela correlação. É de se esperar em sistemas biológicos que alguns genes estejam muito mais ligados que outros, adquirindo um comportamento de centralidade (hub), e quando esse gene é um IncRNA pode-se supor que este gene esteja agindo como um regulador daqueles com os quais ele esteja ligado (Liao, Liu et al. 2011).

\section{Busca por IncRNAs usando análise de redes formadas por WGCNA}


Weighted correlation network analysis (WGCNA), um pacote em R, foi feito com o intuito de analisar dados de expressão gênica como uma rede de coexpressão. A rede de correlação construída pelo WGCNA é uma rede 'com pesos' (weighted), de modo que cada gene é ligado a todos os outros, mas a cada um com uma intensidade diferente, que é medida como o módulo da correlação de pearson elevada a uma constante $\beta$ que serve como um ajuste, dando um peso maior aos valores mais próximos de 1 , em troca de uma possível perda de informação (Zhang and Horvath 2005). Esta medida ajustada de correlação será referida como similaridade.

Além disso os genes são clusterizados, agrupando os genes observados conforme cada um deles se correlaciona com todos os outros, e é atribuído a cada um um valor de conectividade que descreve quanto um gene é central em uma rede, informação a partir da qual pode-se supor que a expressão deste exerce algum tipo de influência sobre os outros genes da rede (Zhang and Horvath 2005).

Esta conectividade é calculada conforme a equação abaixo, onde $a_{i j}$ é a similaridade entre dois genes.

$$
C_{i}=\frac{\sum_{u \neq i} \sum_{\{v \mid v \neq i, v \neq u\}} a_{i u} a_{u v} a_{v i}}{\sum_{u \neq i} a_{i u}\left(\left(\sum_{v \neq i} a_{v i}\right)-a_{u i}\right)}
$$

$\mathrm{C}_{\mathrm{i}}$ é, portanto, a soma da similaridade de todos os genes entre si, normalizados por quanto cada um deles é similar ao gene i (se fosse uma rede sem pesos, onde a ligação entre genes é binária, este seria o número de conexões feitas pelos genes ligados a i), normalizado pela soma das similaridades de i vezes quão mais similar i é que dos outros genes da rede. Em uma analogia usando interações sociais entre pessoas, $C_{i}$ é 1 se todos os seus amigos são amigos entre si, e 0 se nenhum deles se conhece (Zhang and Horvath 2005). 


\section{Objetivos}

1. Realizar uma análise transcriptômica de neutrófilos coletados de pacientes adultos e idosos em choque séptico, para investigar potenciais diferenças de ativação celular que fossem capazes de explicar como são alterados os processos imune e inflamatórios mediados pela resposta inata em pacientes com idade avançada nesta condição.

2. Identificar RNAs não codificadores longos com expressão desregulada na sepse em idosos e adultos jovens e investigar sua contribuição para a regulação da expressão de genes envolvidos na resposta infamatória e imunológica.

\section{Metodologia}

\section{Amostras de RNA de neutrófilos}

Foram analisadas amostras de um total de 24 voluntários, sendo metade amostras de voluntários saudáveis e metade amostras extraídas de pacientes de UTIs em choque séptico. Os controles foram obtidos de indivíduos saudáveis e as amostras de doentes sépticos foram coletadas na Unidade de Terapia Intensiva do Hospital das Clínicas da Faculdade de Medicina da Universidade de São Paulo, após consentimento esclarecido dos indivíduos participantes. As amostras de pacientes em choque séptico são divididas em dois grupos, um com 6 idosos, com em média 77 anos (mínimo 71, máximo de 88), e outro de 6 adultos, com em média 36 anos (mínimo de 25 anos, máximo 45). As amostras controles também se dividem em dois grupos, um com 6 idosos, com em média 78 anos (mínimo 76, máximo de 82 anos), e outro de 6 adultos, com em média 34 anos (mínimo de 28, máximo 38 anos). O sangue dos indivíduos foi coletado e após separação da fração de neutrófilos, o RNA total foi isolado pelo método de TRIzol e mantido congelado a $-80^{\circ} \mathrm{C}$ até sua utilização. 


\section{Experimentos de expressão gênica}

Para avaliar tanto a expressão de genes codificadores de proteínas quanto de IncRNAs foi utilizado o microarranjo de DNA SurePrint G3 Human Gene Expression 8x60K v2 Microarray Kit (da empresa Agilent) que contem 58717 sondas que interrogam todos os genes codificadores de proteína anotados no genoma humano além de lincRNAs (Long intergenic Noncoding RNAs) e de TUCPs (Transcripts of Uncertain Coding Potential), ambos compilados pelo Broad Institute - MIT e Harvard (http://www.broadinstitute.org/genome_bio/human_lincrnas/).

Foi utilizado um protocolo de hibridização de microarranjo em duas cores onde as amostras de RNA foram marcadas fluorescentemente com Cy3 (emissão no verde 570 $\mathrm{nm}$ ) e um RNA de referência, comum a todas as lâminas, foi marcado com Cy5 (emissão no vermelho $670 \mathrm{~nm}$ ). O RNA referência consiste em um pool de RNA de diversos tecidos obtido comercialmente (Universal Human Reference RNA, Agilent, cat \#740000). A utilização de uma referência comum permite normalizar as amostras, de forma a poder observar com um menor viés tanto RNAs mais abundantes quanto os mais raros, garantindo que elas possam ser comparadas com um menor viés experimental possível (Peixoto, Vencio et al. 2006).

\section{Análise dos dados de expressão gênica}

Ao realizar os experimentos de microarranjo foram obtidas imagens da fluorescência dos alvos que hibridizaram por complementaridade às sondas depositadas na lâmina. As imagens foram inicialmente processadas usando o programa Feature Extraction (Agilent) para obtenção dos valores de intensidade de expressão de cada sonda. Após o ajuste de uma máscara para cada sonda, o programa calcula razões entre as intensidades da amostra teste e da referência, e utiliza a abordagem LOWESS (Locally Weighted Scatterplot Smoother) para corrigir diferenças nas medidas de intensidade associadas a diferenças dos fluoróforos utilizados (diferentes eficiências de incorporação, de fluorescência, entre outros), como recomendado na literatura em experimentos de duas cores (Berger, Hautaniemi et al. 2004).

\section{Normalização e filtragem dos dados}


Depois que as amostras foram processadas pelos métodos descritos anteriormente foram extraídas 58717 medições de cada uma das 24 amostras de RNA, foram excluídas as 4259 sondas de controle de qualidade do microarranjo. As medidas de intensidade das lâminas foram normalizadas pelo método do quantil para que estas pudessem ser comparadas entre si. Em seguida foram aplicados filtros para excluir sondas cujas intensidades das medidas fossem inadequadas, ou seja, caso estivessem próximas do ruído experimental (background) ou saturadas.

Para separar as sondas da intensidade muito baixa foi usado o teste chamado "WellAboveBackground" (WAB) para manter apenas as medições mais significativas e aumentar a confiança da análise. O teste WAB é um booleano gerado pelo software Feature Extraction. Consiste em um teste-t que compara quão diferente o sinal detectado é da intensidade de fundo ao redor desta medição, com um intervalo e confiança de $99 \%$. Assim WAB é 0 se o sinal é muito fraco e se assemelha a intensidade medida no background, e 1 se a intensidade medida é significativamente distinta.

Apenas foram consideradas para as análises subsequentes sondas em que pelo menos um dos 4 grupos experimentais (Idosos controle, Idosos com sepse, Adultos controle ou Adultos com sepse) passava no teste WAB (para as duas cores) para todas as amostras avaliadas ou todas menos uma. Essa regra foi criada para excluir sondas que não foram robustamente detectadas nas amostras, mas sem excluir casos em o RNA tem expressão restrita a apenas um dos grupos. Em nenhuma amostra foram observadas sondas saturadas, então não foi estabelecido um protocolo para separá-las.

Outro procedimento importante foi o de calcular o valor médio de sondas replicadas. Alguns transcritos foram interrogados por até oito sondas distintas. Após o filtro WAB foi calculada a média aritmética da intensidade de fluorescência destas sondas e este valor foi utilizado nas análises subsequentes. Após os procedimentos de filtragem descritos acima restaram 16698 sondas, $28 \%$ do total presente no microarranjo.

\section{Análises não supervisionadas dos dados de expressão gênica}

A partir de uma definição de distância que possa ser aplicada para um conjunto de dados uma inteligência artificial pode ser programada para tentar, a partir da distância entre cada par de dados da amostra, usar um algoritmo de clusterização e separar os dados em grupos. Ao usar uma chamada 'Análise não supervisionada', que neste caso 
recebe os valores de intensidade de cada sonda em cada amostra mas não a que grupo de amostras eles pertencem (em contraste com uma análise supervisionada, que usaria essas informações, e portanto buscaria um resultado compatível com a classificação recebida), pode-se testar a existência de similaridades/dissimilaridades nos padrões de expressão gênica subjacentes as amostras (Friedman, Hastie et al. 2009).

Usando um método conhecido como Clusterização hierárquica, um tipo de análise não supervisionada que recebe a medida de expressão dos microarranjos e as compara tomando uma correlação de Pearson como critério de similaridade entre dois genes, e usando como algoritmo de clusterização o UPGMA (Unweighted Pair Group Method with Arithmetic Mean) (Legendre and Legendre 1998) foi gerada a figura abaixo, na qual um dendrograma horizontal denota como as amostras se assemelham entre si, e determina a ordem em que as colunas são dispostas. Para evitar o ruído colocado pelos genes com pouca variação, foram considerados apenas os genes com os $5 \%$ (835) maiores coeficientes de variação.

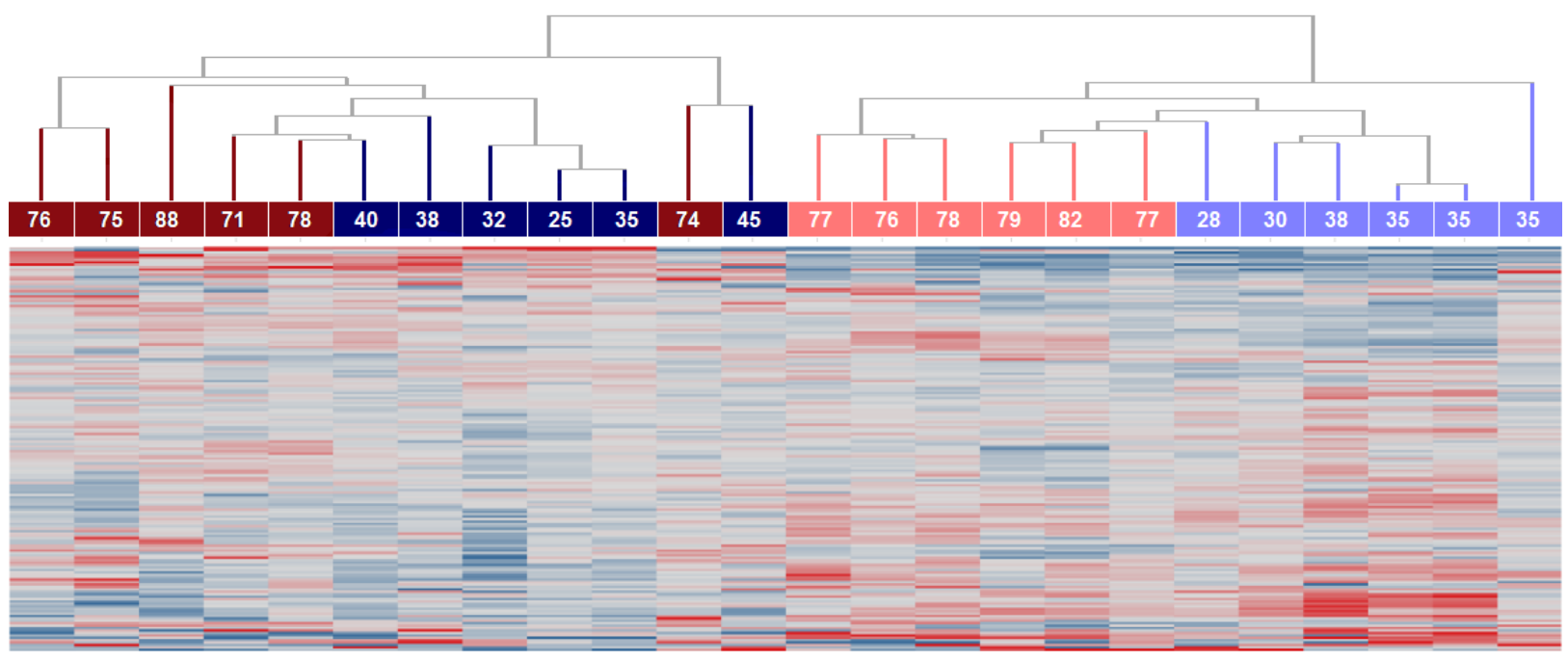

Figura 1: Clusterização hierárquicas dos dados de expressão gênica de indivíduos com sepse e saudáveis, adultos ou idosos. O dendrograma foi colorido para indicar a origem da amostra. Em tons azuis foram pintados os dados de indivíduos adultos ("a") e de tons vermelhos os idosos ("i"). Em tons claros foram pintados os indivíduos controle ("c") e em escuro os afetados por sepse ("s"). No eixo vertical temos os valores de expressão gênica ordenados pelo mesmo método. No quadro (heatmap) cada gene está representado pelo valor normalizado em relação ao seu valor médio em 
todas as amostras (Z-score). Em azul temos os genes com expressão aumentada e em vermelho os genes com expressão diminuída, sendo cinzas os valores intermediários.

Interessantemente conseguimos ver que as amostras se agrupam primeiramente em função da existência ou não de sepse. As amostras são secundariamente agrupadas em função da idade. Este resultado indica a existência de padrões de expressão gênica característicos associados aos diferentes grupos de amostras, reforçando a expectativa de que esses dados possam trazer informações relevantes para o entendimento da sepse e de diferenças na resposta fisiológica e clinica observada entre indivíduos idosos e adultos afetados.

\section{Análise Estatística dos dados de expressão gênica}

Os dados normalizados foram usados para análises estatísticas com o intuito de identificar genes diferencialmente expressos em pacientes idosos e afetados pela sepse. O experimento foi planejado mantendo em mente duas análises comparativas: uma para identificar genes desregulados nos pacientes com sepse, tanto idosos quanto controle, contra os pacientes controles, e outra para encontrar genes desregulados em idosos, tanto pacientes com sepse quanto controles, contra adultos (Pellegrina, Severino et al. 2015). Para cada análise, duas abordagens diferentes foram utilizadas para estimar a significância da diferença de expressão, o Significance Analysis of Microarrays (SAM) (Tusher, Tibshirani et al. 2001) e o RankProduct (RP) (Hong, Breitling et al. 2006), ambos usando pacotes R disponibilizados ao público (Gentleman, Carey et al. 2004) pelo Bioconductor. É muito importante notar que enquanto o SAM compara a expressão entre os grupos pela média e desvio padrão da intensidade das medições (Tusher, Tibshirani et al. 2001), o RP ordena a medição de cada sonda de uma amostra em um vetor e compara as sondas pelo produto das suas posições em cada um desses vetores (Hong, Breitling et al. 2006). A Figura 2 mostra a distribuição dos genes de acordo com o p-valor da diferença de expressão calculado usando o SAM e o RP para diferentes comparações. Cada gráfico mostra, para uma dada comparação, quantos genes possuem p-valor menor que um certo valor (Fig. 2). 

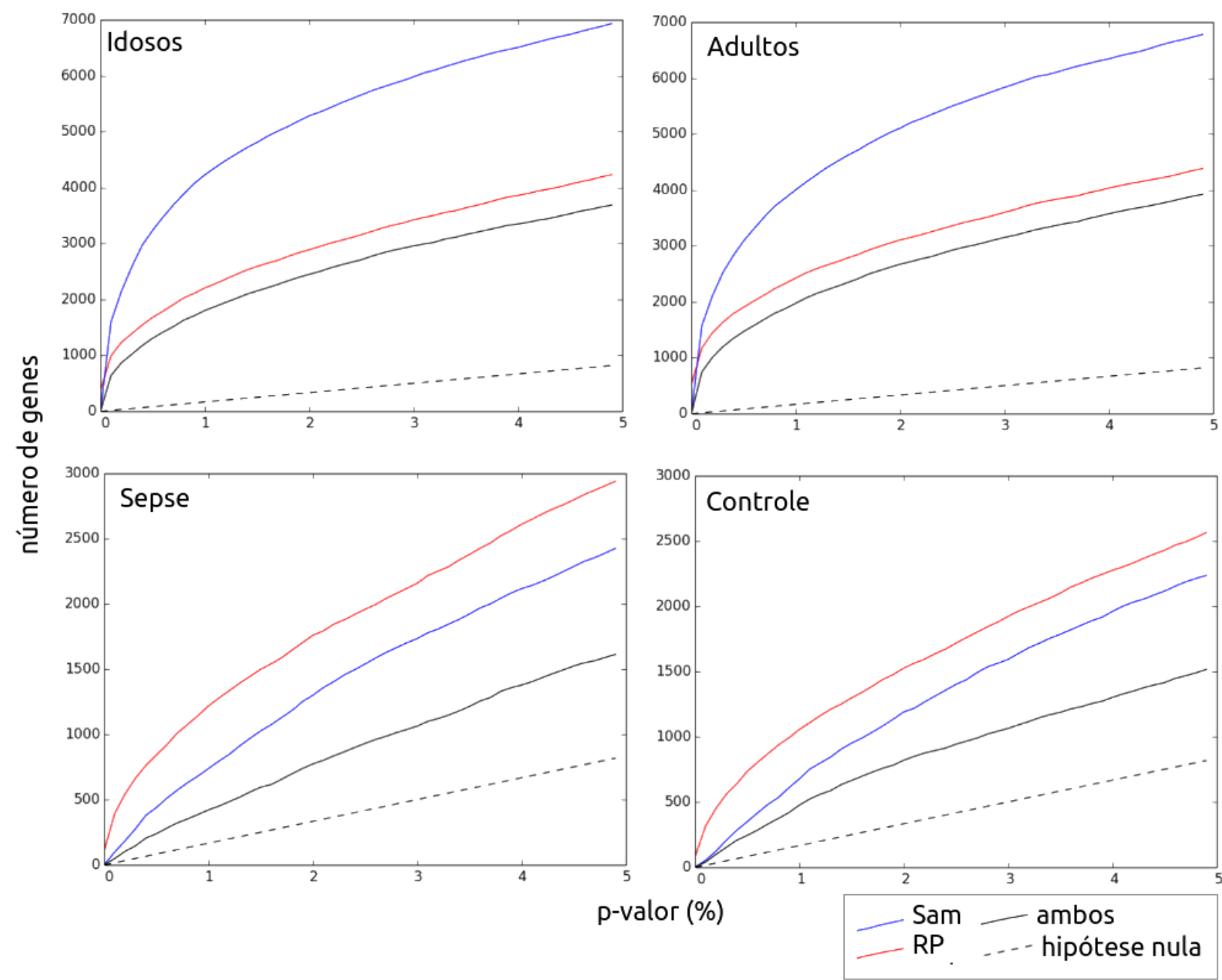

Figura 2: O número de genes considerados significativamente diferencialmente expressos (eixo vertical) para um dado p-valor mínimo (eixo horizontal) de acordo com o SAM (linha azul), de acordo com o RP (linha vermelha), e de acordo com ambos simultaneamente (linha preta). A linha preta tracejada, para comparação, representa uma distribuição uniforme.

Note que as linhas pretas apenas tocam as linhas coloridas (ou seja, que um algoritmo é estritamente mais exigente que o outro) para p-valores bastante altos, sem qualquer significância. Também é importante notar que nenhum dos dois algoritmos é mais exigente que outro em qualquer comparação (nos painéis superiores o RP é menos permissivo, enquanto nos inferiores o SAM é o menos permissivo). É sabido que ambos os algoritmos irão produzir falsos positivos, mas como eles usam algoritmos intrinsecamente diferentes, não há por que esses falsos positivos serem os mesmos (Kadota, Nakai et al. 2009). A partir disso foi adotado o critério de que um gene seria 
significativamente diferencialmente expresso se este fosse identificado com um p-valor $\leq$ 0.01 em ambos os métodos (Pellegrina, Severino et al. 2015).

\section{Reanotação do microarranjo para análise de IncRNAs}

O microarranjo utilizado nos experimentos de expressão gênica (Agilent DNA SurePrint G3 Human Gene Expression 8x60k v2 Microarray) contém 58717 sondas das quais 36075 interrogam mRNAs, 14450 interrogam IncRNAs. Além destas, 5624 sondas não possuíam informações o bastante para se compreender que tipo de transcrito elas estavam interrogando e 2568 sondas não possuíam qualquer tipo de anotação. Realizamos uma reanotação das sondas antes de proceder com a análise dos RNAs codificadores expressos em pacientes com sepse e indivíduos saudáveis, realizando um procedimento muito semelhante ao de Gertz et al. (Gertz, Sengupta et al. 2009).

Foi usado o programa BLAT para comparar as sequências das sondas (fornecidas pelo fabricante) com a montagem GRCh37 do genoma humano. Como o experimento de microarranjo permite a hibridização mesmo com algumas bases não pareadas (mismatches), foram considerados bons alinhamentos aqueles que possuíssem até 1 gap (visto que essa região poderia ser as bordas de dois éxons, que depois se tornam contínuos no RNA maduro), e com até 2 mismatches.

Surpreendentemente um grande número de sondas foram bem alinhadas em mais de um lugar do genoma. Algumas sondas alinhavam em múltiplas regiões de um mesmo gene, ou em genes que foram duplicados, e portanto não faria diferença saber de qual dessas regiões veio o transcrito que se hibridizou com a sonda, pois de todo modo se trataria do mesmo gene. No entanto algumas sondas podem se hibridizar com RNAs provenientes de muitas regiões diferentes do genoma de forma que a intensidade medida pelo microarranjo passa a não ter informação alguma, visto que não se sabe quais são os genes envolvidos. Assim, foram excluídas todas as sondas que alinharam em múltiplos (5 ou mais) locais do genoma (Figura 3 ). 


\section{Excluidos}

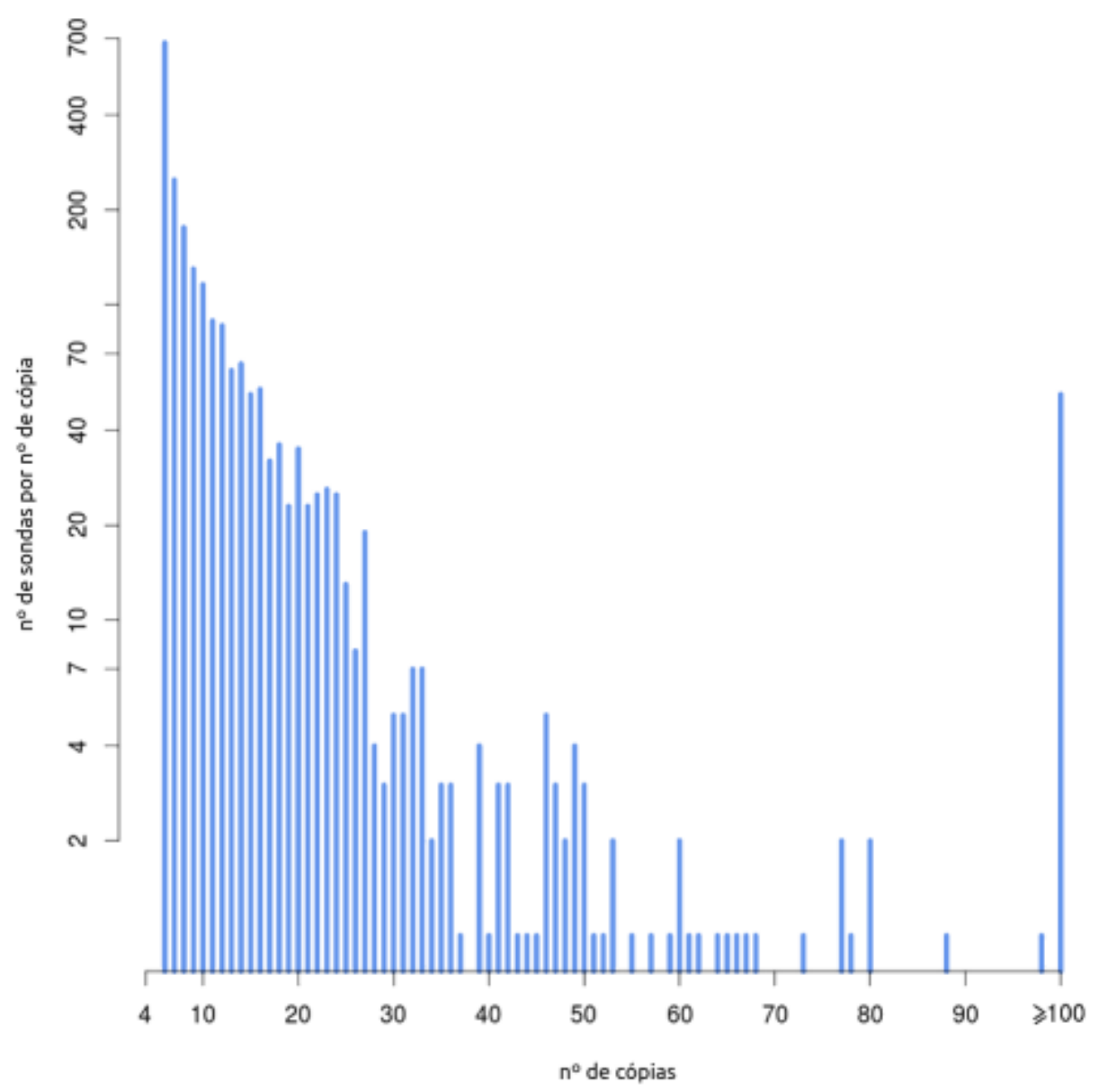

Figura 3: O histograma acima mostra a distribuição de sondas mapeadas com boa qualidade em 5 ou mais locais do genoma. Sondas com mais de 100 alinhamentos foram todas concentradas na marca " $\geq 100$ ".

É de fundamental importância para este projeto uma anotação eficiente das sondas de IncRNAs para poder depois investigar possíveis eventos de regulação mediados por IncRNAs sobre mRNAs. Pela anotação fornecida pelo fabricante foi possível separar as sondas como representantes de transcritos anotados como "mRNA", "ncRNA", "otherRNA", "miscRNA", ou "anotação vazia". Esta classificação não é muito precisa. Além de possuir genes sem nenhuma anotação, não foi encontrada definições precisas para diferenciar "otherRNA" de "miscRNA", e portanto essas duas classes foram unidas como "RNAs de tipo desconhecido".

Para aperfeiçoar a anotação das sondas, foram comparadas as coordenadas genômicas destas (obtidas com o programa BLAT) com as coordenadas de transcritos 
anotados em diferentes bancos de dados com informações sobre anotação de mRNAs, IncRNAs e alguns outros genes do genoma disponibilizados online (NONCode(Xie, Yuan et al. 2014), BROAD Institute (Cabili, Trapnell et al. 2011), LNCipedia (Volders, Helsens et al. 2013), e Gencode (Harrow, Frankish et al. 2012)). O resultado deste cruzamento está apresentado na figura 4.

Como muitas sondas foram alinhadas com regiões do genoma sem nenhuma anotação, e como algumas regiões do genoma possuem mais de uma anotação, foi necessária a adoção de um critério de classificação.

1. Conforme explicado anteriormente, se uma sonda fosse alinhada a muitas (5 ou mais) regiões do genoma ela seria excluída.

2. Se a sonda só for alinhada a regiões sem nenhuma anotação, nem na mesma região da fita oposta, ela seria considerada um "não codificador intergênico desconhecido"

3. Se a sonda só for alinhada a regiões somente com anotações da fita oposta, ela será considerada "não codificador antisenso" do gene anotado.

4. Se a sonda só for alinhada a regiões anotadas como íntrons de um gene, ela será considerada "não codificador intrônico" do gene anotado.

5. Se sonda for alinhada a regiões anotadas de éxons apenas de IncRNAs, ela será considerada um "IncRNA" conforme a anotação encontrada.

6. Se sonda for alinhada a regiões anotadas de éxons de mRNAs, ela será considerada um "mRNA" conforme a anotação encontrada.

7. Se em um dos itens acima houver mais de uma informação, proveniente de diferentes bancos de dados, será dada a preferência segundo a ordem Gencode > Broad Institute > LNCipedia > NONCode.

Pelo fato de que os mecanismos e marcadores do mRNAs foram mais bem estudados, regiões em que são encontrados indícios de existência de um gene codificador, como por exemplo as precedidas por marcas de histona ou Open Reading 
Frames (ORFs), são anotadas como "possíveis mRNAs" mesmo sem ter qualquer pista sobre sua função. Por isso assume-se, tomando os devidos cuidados, que uma região do genoma sem nenhuma anotação seja um ncRNA.

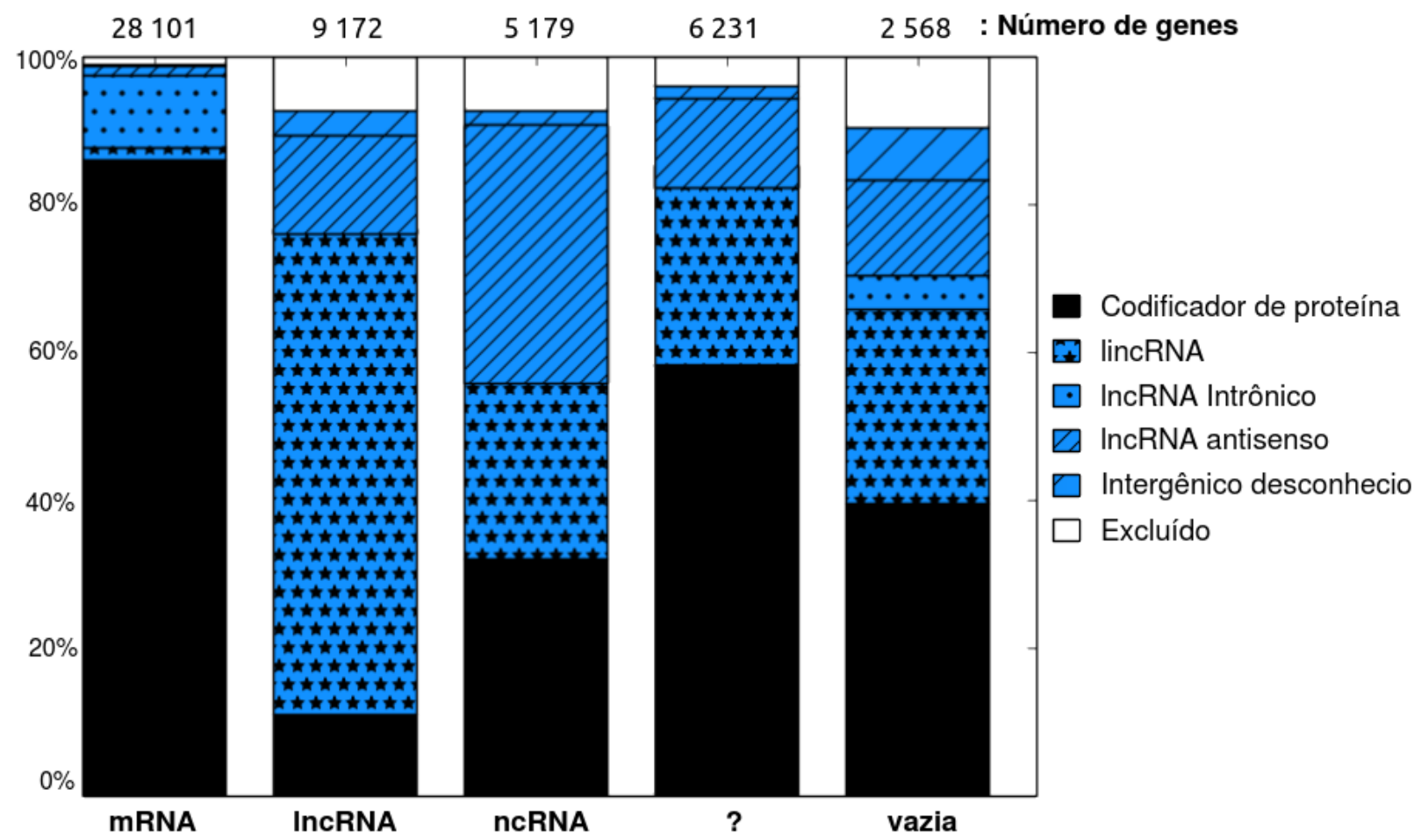

Figura 4: Como era a classificação das sondas, no eixo horizontal, e como ficou depois do processo de reanotação, em cores. Em branco as sondas excluídas por serem alinhadas em mais de 4 posições, em azul as consideradas de genes não codificadores, sendo estes subdivididos em intergênicos desconhecidos, não codificadores antisenso, intrônicos e lincRNAs, e em preto as sondas reanotadas como mRNAs. 
Tabela 1: Conforme a filtragem, as análises estatísticas, e de anotação, foi criada essa tabela que sumariza como as sondas foram classificadas e como os grupos de amostras são representados em termos de expressão diferencial. (sendo SxC sepse versus controle, e AxI adultos versus idosos)

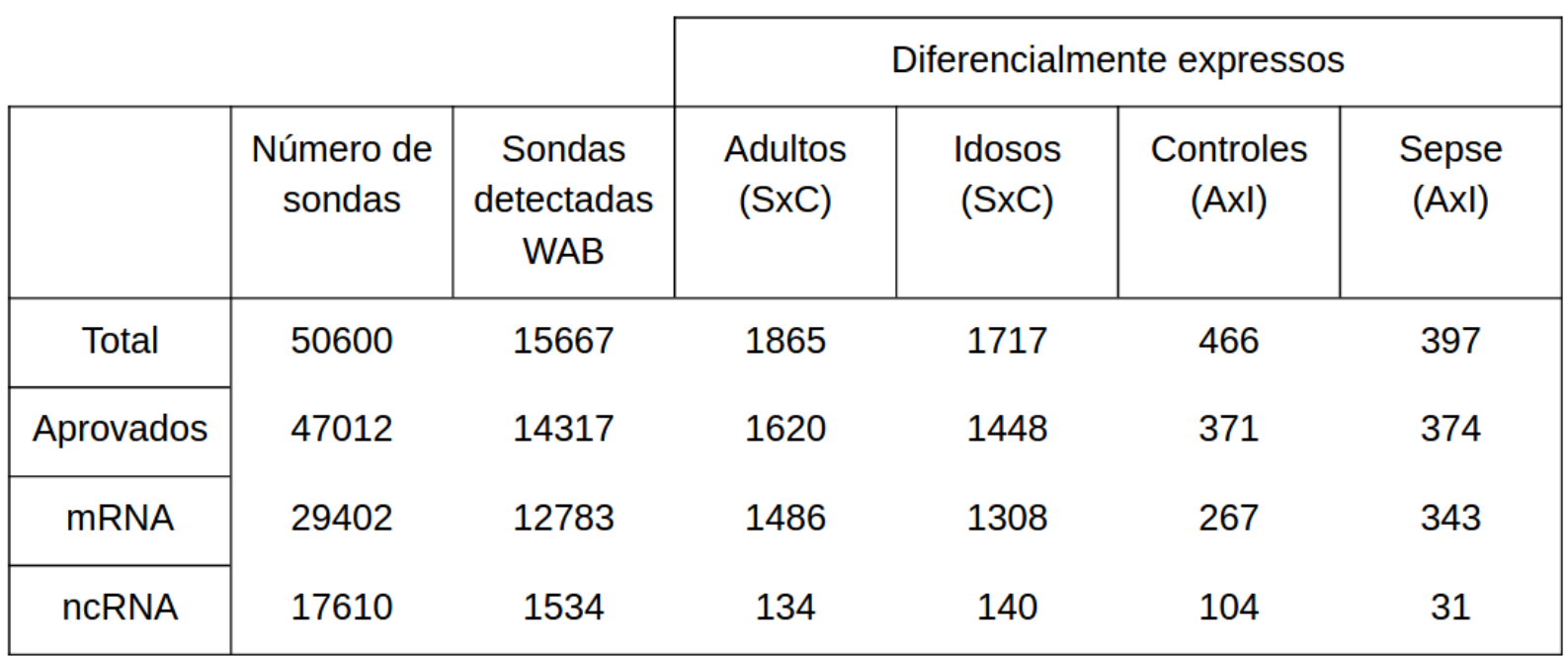

Como resultado desta reanotação foi criada uma tabela que associa cada sonda a um transcrito e dá informações como coordenada, fita, cromossomo, tipo de transcrito, qual banco de dados forneceu estas informações além de como esse transcrito é chamado em diferentes nomenclaturas, como EntrezID, Ensemb/GenelD, EnsembITranscriptID, \#Agilent, e HUGO official gene symbol.

\section{Resultados}

\section{Análise de vias moleculares alteradas na sepse}

Após a seleção de genes diferencialmente expressos usamos o programa Ingenuity Pathways Analysis (IPA) da empresa QIAGEN (Redwood City, www.qiagen.com/ingenuity). Este programa usa bancos de dados alimentados com informações curadas obtidas da literatura para identificar vias moleculares enriquecidas em genes diferencialmente expressos. Foram fornecidas listas com genes identificados 
como diferencialmente expressos com $p$-valor $<1 \%$, tanto via RankProd quanto via SAM. O programa IPA também é informado sobre a classe (Idosos com sepse, Adultos Controle etc.) a qual cada amostra pertence e compara quais vias estão melhor representadas em uma classe que em outra, assim determinando as vias diferencialmente expressas. O programa usa um teste de Fisher que compara o número de genes na lista de diferencialmente expressos, o número de genes diferencialmente expressos assinalados em cada via molecular, o número de genes conhecidos em cada via, e o número total de genes avaliados. Seria de se esperar de uma distribuição ao acaso que a razão de genes assinalados sobre conhecidos fosse a mesma, tanto dentro de cada via, como para o total. Uma via em que há mais genes que o esperado é considerada enriquecida. Para identificar mudanças transcricionais que possam explicar a base molecular do comportamento da sepse e pacientes idosos, examinamos as vias metabólicas que se expressaram diferentemente em idosos e adultos. Primeiro, identificamos o número de vias canônicas que foram enriquecidas com genes desregulados em idosos. Interessantemente, a maior parte dessas vias eram significativamente enriquecidas apenas no grupo com sepse, ou seja, genes diferencialmente expressos entre sujeitos idosos com sepse e sujeitos adultos com sepse (Tabela 1). As vias de fosforilação oxidativa $\left(p=5,3 \times 10^{-13}\right)$ e disfunção mitocondrial $\left(p=1,4 \times 10^{-10}\right)$ eram as mais enriquecidas em pacientes sépticos idosos, em comparação ao grupo séptico adulto. Outras vias significativamente enriquecidas estão na Tabela 1. A Tabela 2 lista as enzimas e transportadores envolvidos em fosforilação oxidativa que foram diferencialmente expressos em pacientes sépticos idosos. 
Tabela 2: Vias canônicas enriquecidas diferencialmente entre indivíduos idosos e adultos, com ou sem sepse.

\begin{tabular}{|c|c|c|}
\hline \multirow[t]{2}{*}{ Via canônica } & \multicolumn{2}{|c|}{ Idosos vs. Adultos } \\
\hline & Controle & Sepse \\
\hline Oxidative phosphorylation & $1,95 \mathrm{E}-001$ & $5,28 \mathrm{E}-013$ \\
\hline Mitochondrial dysfunction & 8,98E-002 & $1,41 \mathrm{E}-010$ \\
\hline ERK5 signaling & - & $9,37 \mathrm{E}-004$ \\
\hline NRF2-mediated oxidative stress response & $2,58 \mathrm{E}-001$ & $5,23 \mathrm{E}-003$ \\
\hline Bile acid biosynthesis neutral pathway & $1,50 \mathrm{E}-002$ & $2,14 \mathrm{E}-001$ \\
\hline dTMP de novo biosynthesis & $1,00 \mathrm{E}+000$ & $3,23 \mathrm{E}-003$ \\
\hline GADD45 signaling & - & $4,75 \mathrm{E}-003$ \\
\hline DNA damage-induced $14-3-3 \sigma$ signaling & - & $4,75 \mathrm{E}-003$ \\
\hline TWEAK signaling & $1,22 \mathrm{E}-002$ & 4,57E-001 \\
\hline
\end{tabular}

Tabela 3: Genes da via de fosforilação oxidativa diferencialmente expressos entre indivíduos idosos e adultos com sepse.

\begin{tabular}{llcc}
\hline Sigla & Nome do gene & expressão idosos/adultos & p-valor \\
\hline NDUFA4 & NADH dehydrogenase (ubiquinone) 1 alpha subcomplex, 4 & 0,69 & $1,90 \mathrm{E}-04$ \\
MT-CO1 & Mitochondrially encoded cytochrome c oxidase I & 0,74 & $2,80 \mathrm{E}-03$ \\
SDHC & Succinate dehydrogenase complex, subunit C & 0,83 & $6,40 \mathrm{E}-03$ \\
ATP5G3 & ATP synthase, H+ transporting, mitochondrial F0 complex, subunit C3 & 0,80 & $1,00 \mathrm{E}-03$ \\
COX5A & Cytochrome c oxidase subunit Va & 0,83 & $1,90 \mathrm{E}-03$ \\
COX6C & Cytochrome c oxidase subunit Vic & 0,79 & $5,50 \mathrm{E}-03$ \\
NDUFA8 & NADH dehydrogenase (ubiquinone) 1 alpha subcomplex, 8 & 0,81 & $1,40 \mathrm{E}-03$ \\
ATP5F1 & ATP synthase, H+ transporting, mitochondrial F0 complex, subunit B1 & 0,83 & $3,20 \mathrm{E}-03$ \\
NDUFB4 & NADH dehydrogenase (ubiquinone) 1 beta subcomplex, 4 & 0,84 & $4,00 \mathrm{E}-03$ \\
ATP5H & ATP synthase, H+ transporting, mitochondrial F0 complex, subunit d & 0,83 & $5,00 \mathrm{E}-03$ \\
NDUFB9 & NADH dehydrogenase (ubiquinone) 1 beta subcomplex, 9 & 0,83 & $1,40 \mathrm{E}-03$ \\
COX7C & Cytochrome c oxidase subunit VIlc & 0,78 & $2,50 \mathrm{E}-03$ \\
UQCRB & Ubiquinol-cytochrome c reductase binding protein & 0,83 & $1,70 \mathrm{E}-03$ \\
COX11 & COX11 homolog, cytochrome c oxidase assembly protein & 0,81 & $7,50 \mathrm{E}-03$ \\
ATP5O & ATP synthase, H+ transporting, mitochondrial F1 complex, O subunit & 0,82 & $2,40 \mathrm{E}-03$ \\
UQCRH & Ubiquinol-cytochrome c reductase hinge protein & 0,82 & $3,10 \mathrm{E}-03$ \\
COX7A2 & Cytochrome c oxidase subunit VIlla polypeptide 2 & 0,84 & $1,50 \mathrm{E}-03$ \\
UQCRQ & Ubiquinol-cytochrome c reductase, complex III subunit VII & 0,85 & $3,00 \mathrm{E}-03$ \\
\hline & & &
\end{tabular}

A seguir, foi feita uma análise de enriquecimento das vias de genes diferencialmente expressas em pacientes sépticos quando comparados ao grupo controle. Muitas vias foram identificadas, mas nenhuma mostrou enriquecimento 
significativamente diferente em idosos quando comparados a adultos. Vias moduladas durante a sepse, como a sinalização $\mathrm{Cdc} 42$, a sinalização fosfolipase $C$, a sinalização interleucina 17 (IL-17), a via de ubiquitinação de proteína, o receptor glucocorticóide e o receptor p38 MAP quinase foram também observadas.

Para melhor identificar as vias moleculares afetadas pela sepse preferencialmente nos idosos, foi refeita a análise usando o subgrupo dos genes que eram diferencialmente expressos nos idosos mas não nos adultos (944 genes). Vias canônicas mais alteradas em idosos com sepse são mostradas na Tabela 3. Notavelmente, durante a sepse, a via do TGF- $\beta$ (transforming growth factor $\beta$ signaling) foi modulada tanto nos idosos quanto nos adultos, no entanto deve-se notar que além de um maior número de genes superregulados, muitos genes desta via são diferencialmente expressos apenas nos idosos ou apenas nos adultos (Tabela 4).

Tabela 4: Vias canônicas enriquecidas com genes alterados em indivíduos idosos com sepse comparado aos idosos controle mas não em indivíduos adultos com sepse comparado aos adultos controle.

\begin{tabular}{lr}
\hline Vias canônicas & p-valor \\
\hline TGF- $\beta$ signaling & $5,8 \mathrm{E}-05$ \\
Factors promoting cardiogenesis in vertebrates & $6,8 \mathrm{E}-05$ \\
Role of osteoblasts, osteoclasts and chondrocytes in rheumatoid arthritis & $4,9 \mathrm{E}-04$ \\
Ga12/13 signaling & $2,1 \mathrm{E}-03$ \\
Cardiomyocyte differentiation via BMP receptors & $2,9 \mathrm{E}-03$ \\
Wnt/ $\beta$-catenin signaling & $4,2 \mathrm{E}-03$ \\
Cholecystokinin/Gastrin-mediated signaling & $4,5 \mathrm{E}-03$ \\
Role of macrophages, fibroblasts and endothelial cells in rheumatoid arthritis & $4,5 \mathrm{E}-03$ \\
Calcium signaling & $4,7 \mathrm{E}-03$ \\
BMP signaling pathway & $5,6 \mathrm{E}-03$ \\
NGF signaling & $5,9 \mathrm{E}-03$ \\
\hline
\end{tabular}


Tabela 5: Genes da via do TFG- $\beta$ diferencialmente expressos em idosos.

\begin{tabular}{llc}
\hline Sigla & Nome do gene & expressão sepse/controle \\
\hline BMP7 & Bone morphogenetic protein 7 & 1,19 \\
CREBBP & CREB binding protein & 1,15 \\
INHBB & Inhibin beta B & 1,53 \\
SERPINE1 & Serpin peptidase inhibitor clade E (nexin plasminogen activator inhibitor type & 1,29 \\
\hline SMAD4 & 1) member 1 & 1,10 \\
SMAD9 & SMAD family member 4 & 1,08 \\
TGFB1 & Transforming growth factor beta 1 & 1,13 \\
\hline
\end{tabular}

A ferramenta IPA também foi utilizada para identificar possíveis reguladores transcricionais (upstream regulators) com atividade alterada na sepse. Estas alterações não são detectadas diretamente pela expressão das sondas correspondentes no microarranjo. A ferramenta IPA infere as mudanças de atividade nos upstream regulators a partir da observação de mudanças na expressão (ativação ou repressão) de genes sabidamente regulados por estes reguladores. Entre os upstream regulators identificados, foi focada a análise daqueles preditos como superexpressos em idosos com sepse mas subexpressos em idosos controle, ou naqueles que eram superexpressos em idosos controle mas subexpressos em idosos com sepse (Tabela 5). Interessantemente, entre eles estão incluídos alguns reguladores de vias detectadas nas análises anteriores, entre eles o ERK e o TGF- $\beta 1$. Além desses, foram encontrados miRNAs que podem estar ativados (miR-590-3p) ou inibidos (miR-141-3p, miR-186-5p) em idosos com sepse, assim como compostos que podem ter um papel regulatório nesses pacientes sugerindo potenciais alvos terapêuticos (Tabela 5). 
Tabela 6: Upstream regulators preditos com atividade invertida entre idosos e adultos.

\begin{tabular}{|c|c|c|c|c|}
\hline \multirow[t]{3}{*}{ Upstream Regulators } & \multicolumn{4}{|c|}{ Idosos vs. Adultos } \\
\hline & \multicolumn{2}{|c|}{ Controle } & \multicolumn{2}{|c|}{ Sepse } \\
\hline & z-valor & p-valor & z-valor & p-valor \\
\hline miR-590-3p (miRNAs w/seed AAUUUUA) & $-0,75$ & 0,025 & 2,85 & 0,011 \\
\hline INSR & 1,95 & 0,035 & $-1,63$ & 0,000 \\
\hline ERK & $-0,79$ & 0,003 & 2,74 & 0,012 \\
\hline GnRH analog & $-0,90$ & 0,011 & 2,50 & 0,003 \\
\hline miR-141-3p (miRNAs w/seed AACACUG) & 2,30 & 0,275 & $-0,95$ & 0,020 \\
\hline Phorbol myristate acetate & $-1,67$ & 0,022 & 1,48 & 0,006 \\
\hline TP63 & $-0,44$ & 0,028 & 1,97 & 0,080 \\
\hline Phorbol esters & $-0,49$ & 0,005 & 1,72 & 0,002 \\
\hline Cg (Choriogonadotropin) & $-0,93$ & 0,046 & 0,80 & 0,032 \\
\hline SB203580 (kinase inhibitor) & 1,40 & 0,017 & $-0,16$ & 0,012 \\
\hline TGFB1 & $-0,44$ & 0,030 & 1,00 & 0,034 \\
\hline PD98059 (kinase inhibitor) & 0,41 & 0,014 & $-0,55$ & 0,019 \\
\hline MAP2K4 & $-0,76$ & 0,007 & 0,15 & 0,015 \\
\hline miR-186-5p (miRNAs w/seed AAAGAAU) & 0,03 & 0,016 & $-0,36$ & 0,008 \\
\hline
\end{tabular}

\section{Validação por q-PCR}

Para suportar a análise dos dados de microarranjo, foram feitos experimentos de transcrição reversa seguida de PCR quantitativo, RT- $q P C R$, para validar a expressão de genes candidatos identificados nas análises. Os experimentos de RT-qPCR foram realizados pela Dra. Patrícia Severino (IEP-HIAE). Foram selecionados os seguintes genes: 1) NDUFA4 e SDHC, envolvidos na respiração celular; 2) INHBB, TGFB1 e CREBBP, componentes da via do TGF- $\beta$; 3) HDAC4 e SRC também foram investigados por serem genes significativamente alterados em idosos, mas sua expressão foi nula nos dois grupos de adultos.

De modo geral, foi observada uma boa associação entre os dados de RT-qPCR e microarranjo (Correlação de Pearson = 0,68, $\mathrm{p}<0,05$ ). NDUFA4, SDHC, e INHBB foram confirmados como expressos e significativamente alterados conforme esperado $(p<$ 0,.02). Os resultados de RT-qPCR dos genes TGFB1 e HDAC4 tiveram sua expressão confirmada e apresentaram a mesma tendência das medidas do microarranjo, mas devido às grandes margens de erro apresentadas no experimento as medidas não foram consideradas significativas. CREBBP e SRC se mostraram inconclusivos devido ao fraco 
sinal. De modo geral, esses resultados puderam ser utilizados para dar suporte às nossas observações.

\section{Construção de redes de coexpresão usando WGCNA}

O programa WGCNA foi usado para criar duas redes, uma para os 12 idosos, e outra para os 12 adultos, e todos os genes que passaram pelo critério WAB foram usados em ambos casos (Langfelder and Horvath 2008).

As correlações foram ajustadas usando um fator exponencial $\beta$ de 13, escolhido conforme 0 procedimento indicado no tutorial do WGCNA (labs.genetics.ucla.edu/horvath/CoexpressionNetwork/Rpackages/WGCNA/Tutorials/) pois permitiu a melhor clusterização em adultos e idosos. Como não foi observado um padrão claro, foi escolhido arbitrariamente que o número de clusteres seria 10 (o fator cutHeight foi ajustado até que este fosse número de clusteres obtido). Na figura 5 estão disponíveis duas barras coloridas horizontais que mostram a clusterização original, e a reduzida para 10 clusteres.

A partir destas redes, foi obtida a conectividade de cada gene para idosos e para adultos. E na figura 6 é mostrado cada um dos genes, em função da sua conectividade (eixo y), e da razão com que ela varia na rede dos idosos e na rede dos adultos (eixo x).

A primeira observação importante a ser feita nesta mesma figura é que os genes diferencialmente expressos na sepse se concentram entre os mais conexos, ou hubs. As cores dos pontos representam a significância da diferença de expressão, sendo os azuis os mais significativos. Visto que estas são células do sistema imunológico que têm suas funções celulares ligadas à sepse, e que, como mostrado anteriormente, possuem uma profunda alteração a nível transcricional nos casos de sepse, é de se esperar que os genes hubs estejam entre os diferencialmente expressos. 


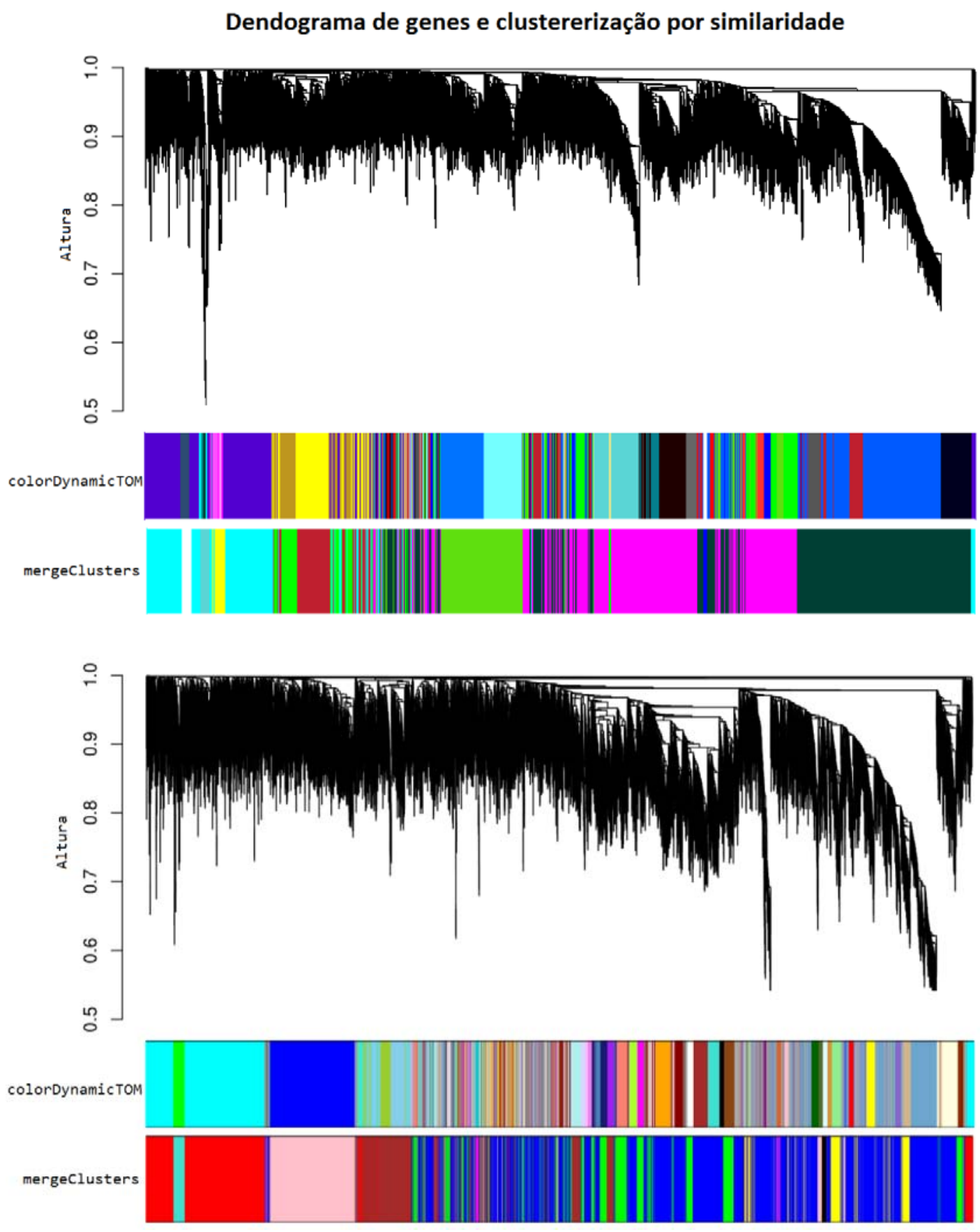

Figura 5: Dendograma dos genes usando similaridade como critério de construção, para idosos acima, para adultos abaixo. Para cada rede foi usado dynamicTOM overlap para fazer a clusterização. Nas barras verticais genes com a mesma cor se encontram no mesmo cluster. A primeira barra de cada dendograma representa a clusterização sem um limite pré-estabelecido de clusteres, a segunda mostra uma limitada a 10 clusteres. 


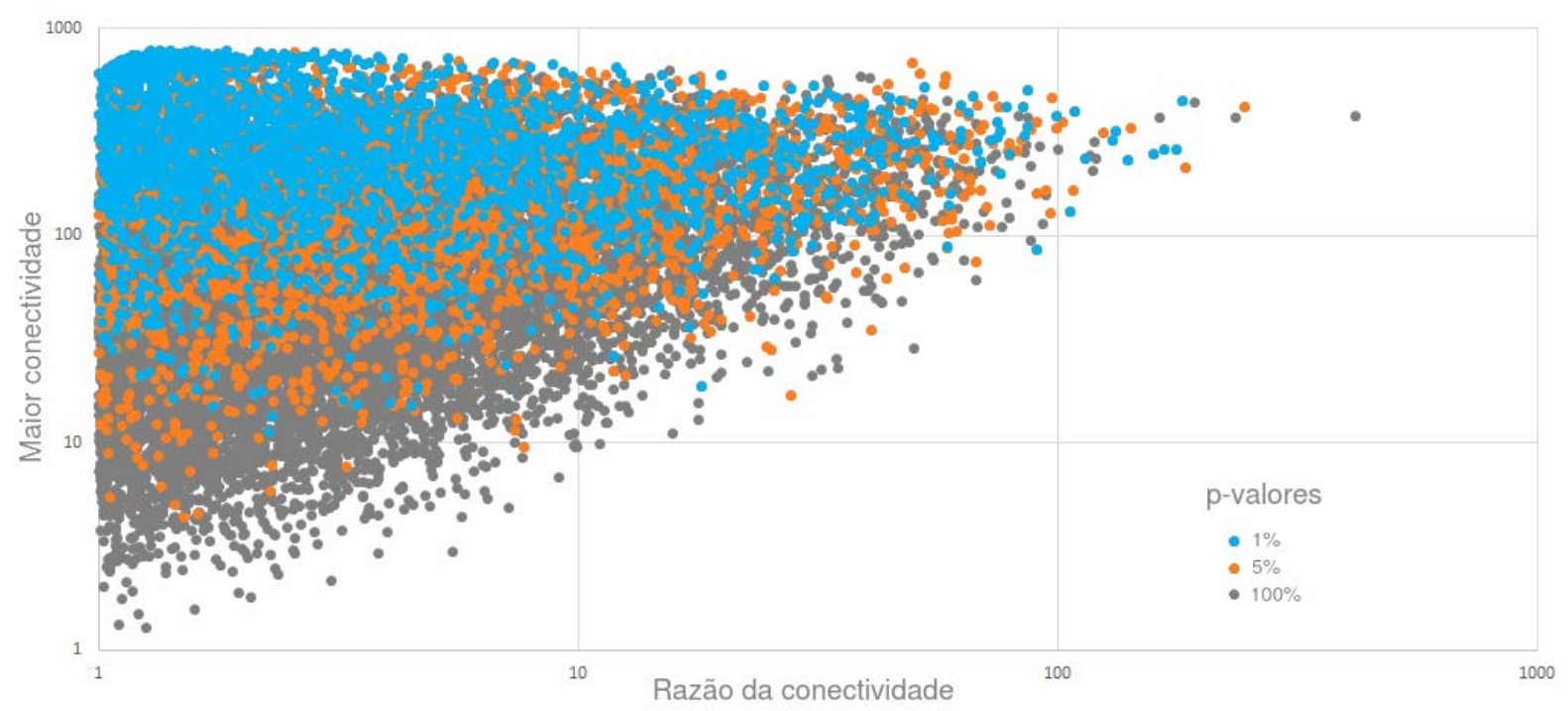

Figura 6: Nesta figura cada ponto mostra um gene, e sua cor representa o pvalor atribuído como gene diferencialmente expresso entre os grupos sepse e os grupos de controle. Os pontos estão distribuídos no eixo vertical em função da conectividade maior atingida em uma das duas redes, e no eixo horizontal se distribuem em função da razão da conectividade entre as duas redes.

A conectividade aferida aos genes observados foi utilizada para separar dois grupos dos genes diferencialmente expressos (1\% de p-valor), conforme mostrado na figura abaixo. O grupo superior é o dos $15 \%$ mais hubs. O grupo da direita são hubs os que possuem mais significativa diferença de conectividade entre idosos e adultos, para não fazer uma análise sobre genes muito pouco conexos mas com grande variação, esse grupo foi definido como os $10 \%$ com maior produto conectividade média e razão das conectividades (entre adultos e idosos) e foi chamado de 'diferentes'. Esta divisão foi feita com o intuito de selecionar, no primeiro grupo quais genes seriam mais centrais em relação à sepse, e no segundo grupo quais genes seriam os mais centrais na relação entre a sepse e o envelhecimento. É importante notar que, em concordância com o observado na figura 6 todos os genes nestes grupos foram agrupados em clusteres que, como um todo, é de expressão altamente correlacionada com a sepse, pelo menos 0,8 em média. 


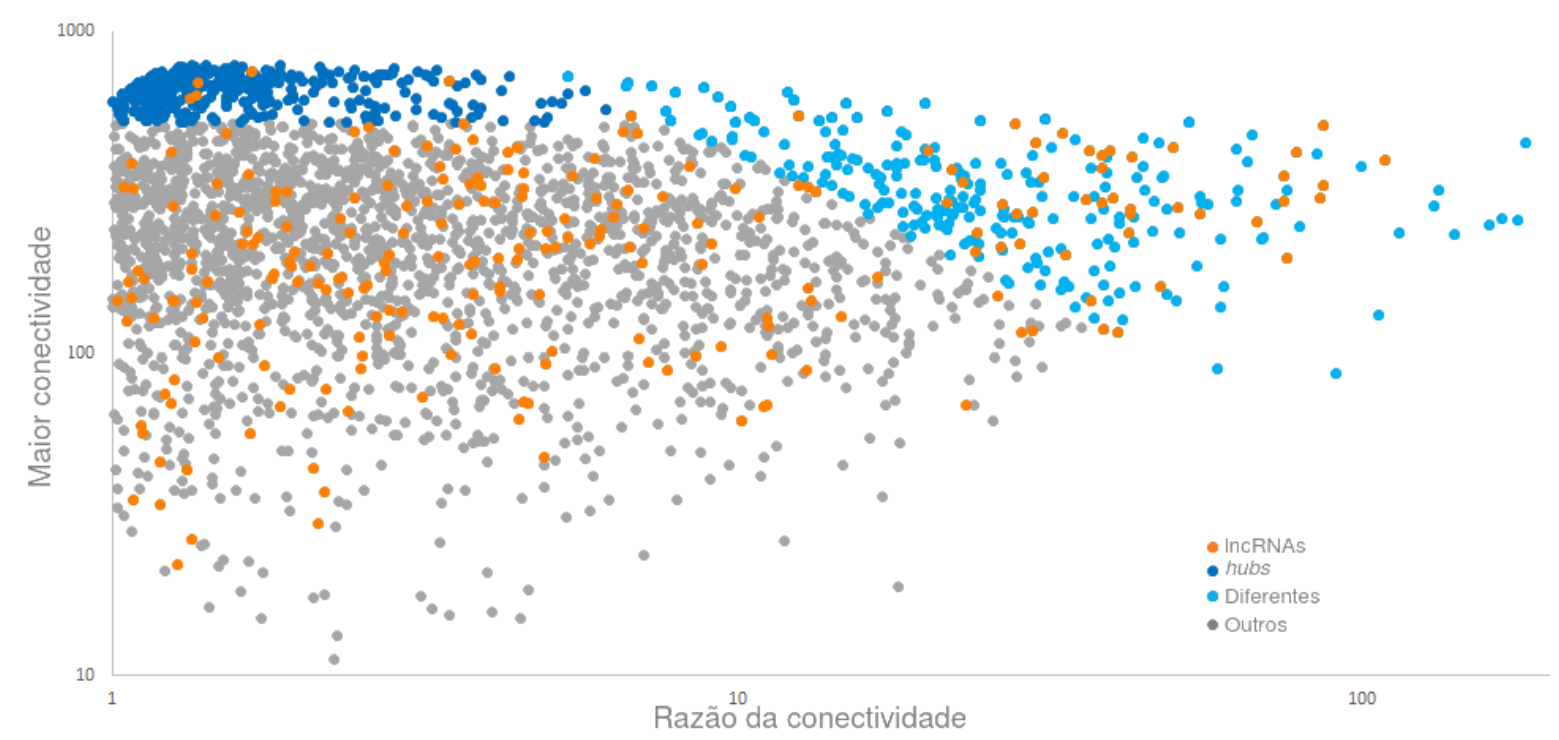

Figura 7: Novamente os pontos estão distribuídos no eixo vertical em função da conectividade maior atingida em uma das duas redes, e no eixo horizontal se distribuem em função da razão da conectividade entre as duas redes. Apenas os genes com diferença de expressão na sepse ( $p$-valor de 1'\%) estão mostrados. Os genes marcados em azul pertencem ao grupo dos mais hubs, os cianos os com maior diferença de conectividade, e em laranja os genes considerados não codificadores. Note que existe uma sobreposição de cores, por exemplo os genes coloridos como laranjas cercados de genes coloridos como azuis também são hubs.

Para entender o contexto destes grupos foi usado DAVID (Huang, Sherman et al. 2009) uma ferramenta de análise de enriquecimento de vias, que recebe uma lista de genes escolhidos e outra lista com todos os observados (background), e calcula quais as vias mais enriquecidas proporcionalmente à sua representatividade no conjunto do qual os genes foram selecionados. Para cada um desses grupos DAVID foi usado, e como background foram colocados todos os genes considerados diferencialmente expressos. 
Tabela 7: Quais as vias mais enriquecidas, segundo DAVID, para os genes selecionados em cada um dos grupos selecionados pela conectividade.

\begin{tabular}{|c|c|c|}
\hline Grupo: & Via mais enriquecida & $2^{\text {a }}$ via mais enriquecida \\
\hline Hubs & Ribossome, $\mathrm{p}<0,01 \%$ & rRNA processing, $\mathrm{p}=0,01 \%$ \\
\hline Diferentes & Mitochondrion, $\mathrm{p}=0,7 \%$ & Oxiredutase, $\mathrm{p}=4 \%$ \\
\hline
\end{tabular}

Em cada um desses grupos alguns genes foram anotados como IncRNAs, 8 no primeiro grupo, 48 no segundo. Para cada um desses IncRNAs foi observado qual a medida de similaridade com os genes pertencentes às vias apontadas pelo DAVID. Para cada um desses grupos alguns membros estão mais bem conectados aos membros das vias enriquecidas, e que portanto são candidatos para validação em estudo experimental como IncRNAs ligados à regulação de genes envolvidos na atividade de ribossomos durante a sepse, para os 5 IncRNAs selecionados do primeiro grupo, e como IncRNAs ligados à regulação de genes da mitocôndria durante a sepse e ligado a disfunções relacionadas à idade, no caso dos 4 selecionados do segundo grupo.

Para os IncRNAs selecionados foram feitos, usando a ferramenta Cytoscape, grafos que permitem visualizar as redes que se formaram. Para tornar a rede visualmente inteligível só são mostradas as conexões mais com maior similaridade, e somente as interações de ncRNAs com mRNAs.

Tabela 8: Algumas informações sobre os genes não codificadores mais bem ligados a genes sabidamente pertencentes às vias mais bem envolvidas com genes de alta conectividade.

\begin{tabular}{|c|c|c|c|c|c|c|c|}
\hline \multirow[b]{2}{*}{ Gene } & \multicolumn{2}{|c|}{ Conectividade } & \multirow{2}{*}{$\begin{array}{l}\text { Vias enriquecidas } \\
\text { pelos vizinhos }\end{array}$} & \multicolumn{4}{|c|}{ Expressão média } \\
\hline & Idosos & Adultos & & \begin{tabular}{|l|} 
Idosos \\
Sepse
\end{tabular} & \begin{tabular}{|l} 
Idosos \\
Controles
\end{tabular} & \begin{tabular}{|l|} 
Adultos \\
Sepse
\end{tabular} & $\begin{array}{l}\text { Adultos } \\
\text { Controles }\end{array}$ \\
\hline KCTD21-AS1 & 755.2 & 451.9 & Ribossomo & 20.32 & 18.06 & 18.75 & 19.95 \\
\hline AC093323.3 & 697.4 & 508.4 & Ribossomo & 0.73 & 0.93 & 0.75 & 0.96 \\
\hline AC010240.2 & 547.8 & 43.8 & Mitocôndria (Idosos) & 0.56 & 0.56 & 0.52 & 0.61 \\
\hline Inc-C12orf77-2 & 515.2 & 18.6 & Mitocôndria (Idosos) & 0.04 & 0.07 & 0.05 & 0.07 \\
\hline Inc-STX17-1 & 5.9 & 510.5 & Mitocôndria (Adultos) & 0.07 & 0.11 & 0.06 & 0.10 \\
\hline MYCNOS & 4.0 & 297.6 & Mitocôndria (Adultos) & 0.18 & 0.21 & 0.15 & 0.22 \\
\hline MALAT1 & 6.5 & 273.4 & Mitocôndria (Adultos) & 2.13 & 2.57 & 2.15 & 2.52 \\
\hline
\end{tabular}


Via do ribossomo:

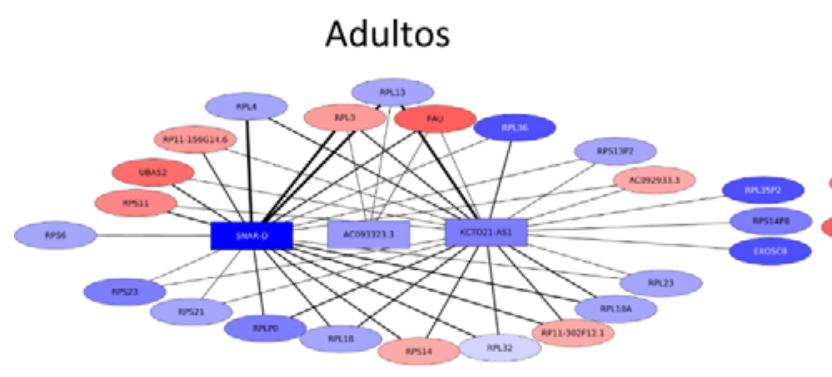

Via da mitocôndria:

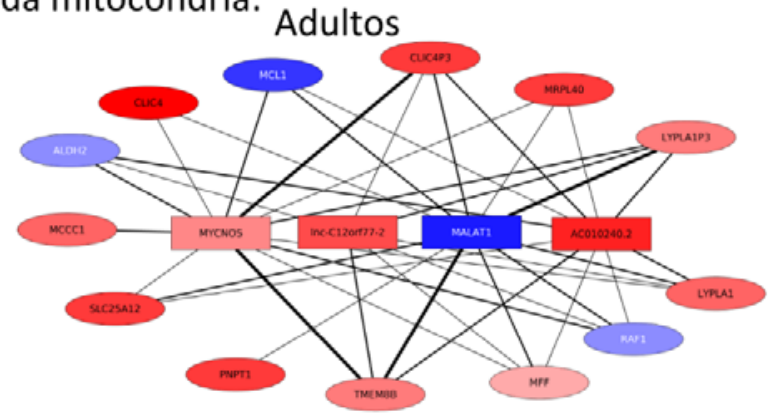

Idosos

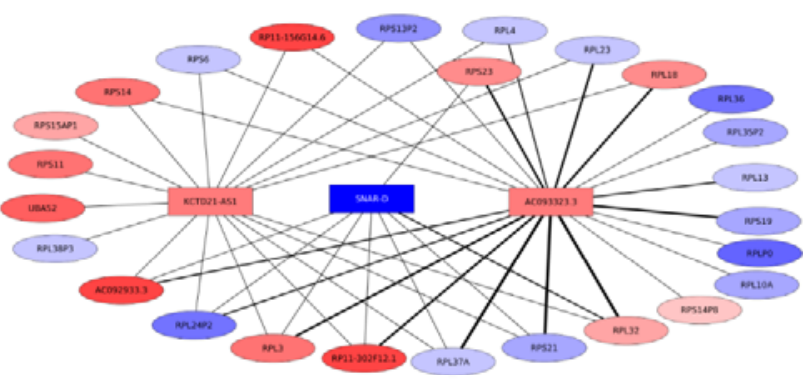

Idosos

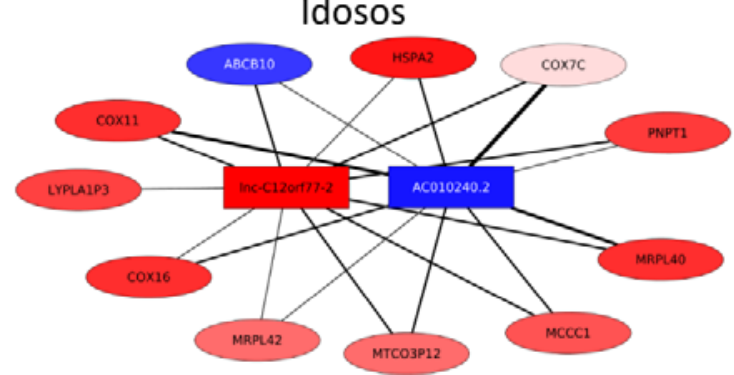

Figura 10: Em retângulos os ncRNAs mais bem conectados ao mRNAs, em elipses, selecionados por participarem de uma das vias metabólicas enriquecidas, sendo que a espessura das linhas é uma representação gráfica desta intensidade. Em azul os genes mais expressos na sepse, e em vermelho os mais expressos entre os controles.

\section{Visualização de alguns IncRNAs hubs no Genome Browser}

O Genome Browser (Kent, Sugnet et al. 2002) é uma ferramenta web que usa vários bancos de dados públicos, como o Gencode (Harrow, Frankish et al. 2012) por exemplo, e os apresenta em uma interface gráfica, permitindo que sejam observadas as coordenadas dos genes, a estrutura dos éxons, além de muitas outras informações, como marcas de cromatina ou a conservação das sequências (baseado no alinhamento contra 100 outras espécies de vertebrados).

Nas figuras abaixo é mostrado a posição dos genes relativo à versão GRCh37 do genoma (apontada por uma seta), a estrutura dos éxons, e alguns genes vizinhos. À baixo a conservação da sequência é comparada com 100 diferentes vertebrados, e é um indicativo de como atuam pressões seletivas sobre o gene. Por fim, é mostrada também a afinidade da sequência a algumas marcas de histona, que influenciam na estrutura da 
cromatina e interferem na acessibilidade da RNA polimerase ativando ou inibindo a transcrição.

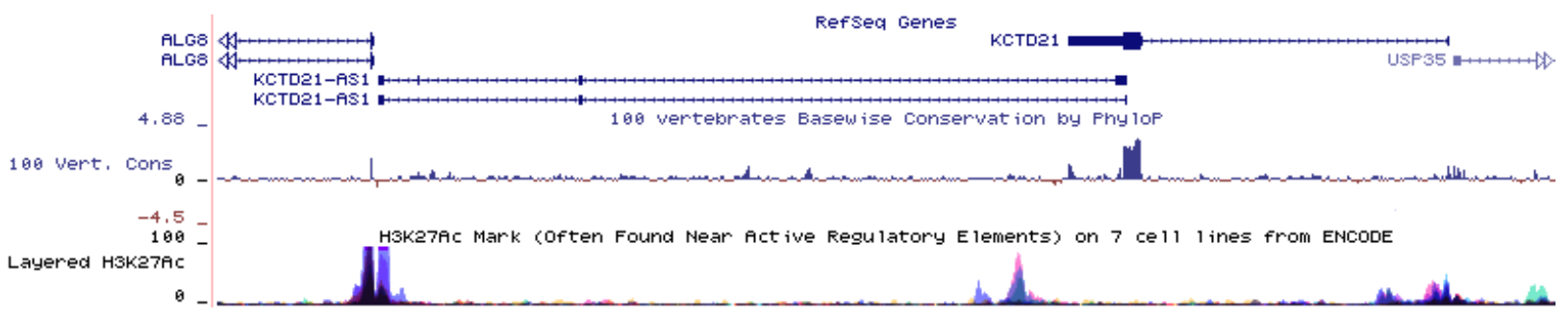

Figura 10: O gene KCTD21-AS1 é um IncRNA conhecido e antisenso ao gene KCTD21, potassium channel tetramerization domain containing 21, componente de um canal de potássio que já foi ligado à atividade citotóxica em células do sistema imunológico (Attali, Romey et al. 1992). Foi o IncRNA com expressão diferencial em sepse mais bem conexo nas redes de co-expressão.

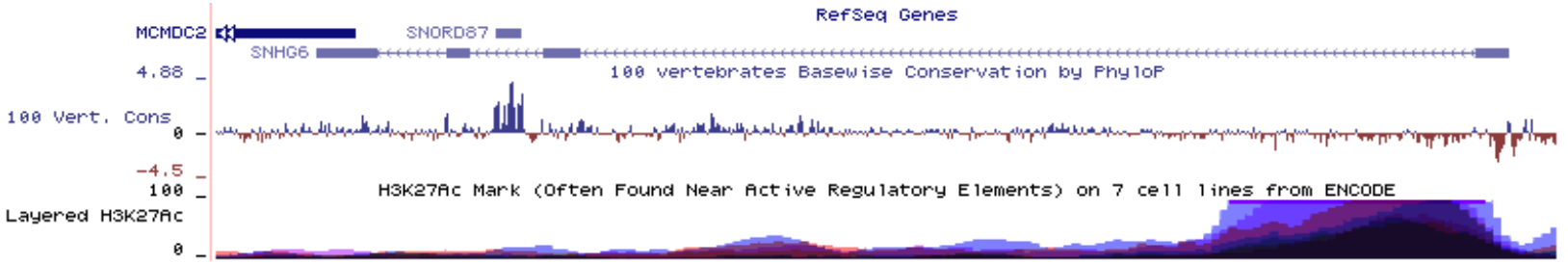

Figura 11: $O$ gene SNHG6 é um small nucleolar $R N A$, ele parece regular MCMDC2, uma proteína sem função conhecida do minichromosome maintenance complex que participa na tradução de proteínas (Li, Zhai et al. 2015). O SNHG6 é um gene muito bem conectado na rede dos idosos, mas consideravelmente menos conectado naa rede dos adultos.

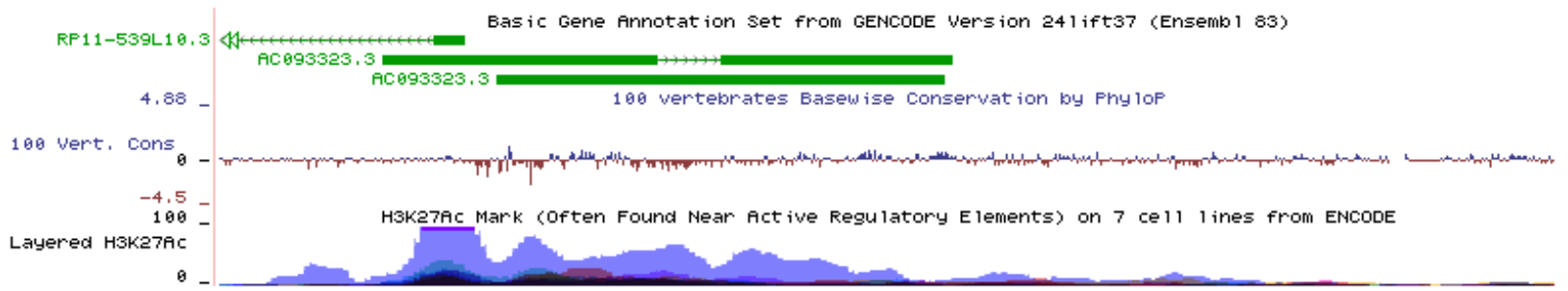

Figura 12: O gene AC093323.3 está entre os genes mais conexos em ambas as redes e diferencialmente expresso na sepse tanto em adultos quanto em idosos, e não há nenhum indício de função para este gene na literatura. 


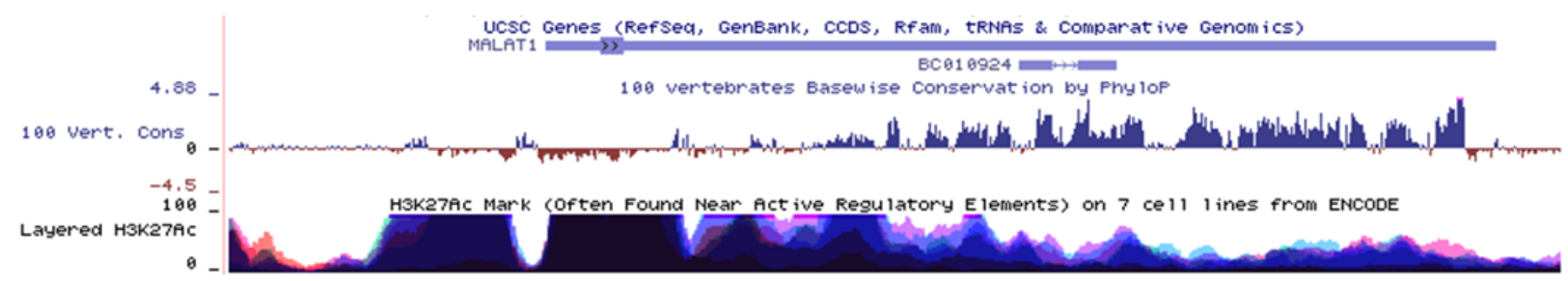

Figura 13: O gene MALAT1, é um IncRNA bastante estudado e já é conhecidamente envolvido em muitos processos biológicos (Wu, Huang et al. 2015), no processo de reanotação das sondas do microarranjo foi observado que três sondas diferentes interrogam este gene em diferentes pontos e com valores bastante distintos, sugerindo a existência de transcritos alternativos. Este gene só é considerado um hub na rede das amostras de adultos, e é muito mais expresso em adultos controle que nos outros grupos.

Tabela 9: Algumas informações sobre genes não codificadores, diferencialmente expressos na sepse, e entre os mais conexos na rede de co-expressão dos adultos ou dos idosos:

\begin{tabular}{|l|r|r|r|r|r|r|}
\hline \multirow{2}{*}{ Gene } & \multicolumn{1}{|c|}{ Conectividade } & \multicolumn{5}{c|}{ Expressão média } \\
\cline { 2 - 7 } & \multicolumn{1}{c|}{ Idosos } & \multicolumn{1}{c|}{ Adultos } & \multicolumn{1}{c|}{$\begin{array}{c}\text { Idosos } \\
\text { Sepse }\end{array}$} & $\begin{array}{c}\text { Idosos } \\
\text { Controle }\end{array}$ & $\begin{array}{c}\text { Adultos } \\
\text { Sepse }\end{array}$ & \multicolumn{1}{c|}{$\begin{array}{c}\text { Adultos } \\
\text { Controle }\end{array}$} \\
\hline KCTD21-AS1 & 755.2 & 451.9 & 20.32 & 18.06 & 18.75 & 19.95 \\
SNHG6 & 705.3 & 204.5 & 9.96 & 11.15 & 10.64 & 11.49 \\
AC093323.3 & 697.4 & 508.4 & 0.73 & 0.93 & 0.75 & 0.96 \\
SNHG8 & 648.4 & 298.2 & 11.08 & 11.96 & 11.56 & 12.75 \\
RP11-452F19.3 & 608.7 & 65.7 & 0.28 & 0.33 & 0.25 & 0.37 \\
EPB41L4A-AS1 & 576.3 & 330.2 & 4.88 & 5.71 & 5.35 & 6.47 \\
SNHG15 & 102.2 & 549.6 & 1.25 & 1.50 & 1.32 & 1.66 \\
AC002386.1 & 545.1 & 80.7 & 0.09 & 0.12 & 0.10 & 0.12 \\
Inc-STX17-1 & 5.9 & 510.5 & 0.07 & 0.11 & 0.06 & 0.10 \\
RP11-499E18.1 & 74.5 & 486.9 & 0.15 & 0.16 & 0.15 & 0.18 \\
RP11-473I1.9 & 123.4 & 464.1 & 1.03 & 1.02 & 1.15 & 1.40 \\
TMPRSS4-AS1 & 24.1 & 463.7 & 2.32 & 3.00 & 2.29 & 2.73 \\
LINC00173 & 32.1 & 454.5 & 0.19 & 0.27 & 0.17 & 0.24 \\
\hline
\end{tabular}




\section{Conclusões}

\section{Contribuições para o entendimento da senescência na sepse}

A partir da análise dos microarranjos de DNA hibridizados com o RNA extraído das amostras, foi mostrado que entre os muitos genes ativados nos neutrófilos durante a sepse, algumas vias moleculares (como por exemplo a via de sinalização do TGF- $\beta$ ) possuem a expressão de muitos dos seus elementos alteradas em indivíduos idosos, apontando vias de especial atenção que estão provavelmente ligadas ao grande aumento da mortalidade entre os idosos na sepse.

A partir da estrutura destas vias, que já são bem documentadas, foi possível inferir que as ações de alguns genes com importante papel regulatório possam estar associadas a este processo (upstream regulators como miR-141-3p, ERK e TGF- $\beta 1$ ). Esses genes são os principais alvos para tratamentos que possam mitigar os efeitos do envelhecimento sobre a sepse, e proporcionar uma diminuição na mortalidade.

\section{Contribuições para a anotação de IncRNAs envolvidos na sepse}

O primeiro passo para estudar a ação de RNAs não codificadores foi o processo de reanotação das sondas do microarranjo, a partir de informações obtidas por meio de diferentes bancos de dados públicos. Esta reanotação mostrou o quanto a anotação de fábrica era deficitária, e permitiu entender melhor qual o universo de pesquisa com que se estava trabalhando, e como selecionar os RNAs não codificadores do transcriptoma.

Para atribuir um contexto a expressão destes IncRNAs foram construídas redes de coexpressão a partir dos dados do transcriptoma. Foram selecionados 56 RNAs não codificadores com comportamento centralizador nestas redes. Considerados importantes para a regulação da sepse, para 11 destes foram encontrados fundamentos para se supor em que moleculares estão atuando sobre uma via molecular (principalmente em genes de função mitocondrial e ribossômica). Uma investigação experimental guiada pelas descobertas e predições deste estudo está sendo iniciada, visando alvos moleculares para tratamento em idosos e o uso de IncRNAs como biomarcadores para a sepse. 


\section{Publicações geradas por este trabalho}

A primeira parte deste trabalho, que trata da análise dos genes bem anotados e das vias moleculares alteradas na sepse em função da senescência, gerou uma publicação na revista PLoS ONE entitulado "Septic Shock in Advanced Age: Transcriptome Analysis Reveals Altered Molecular Signatures in Neutrophil Granulocytes.".

- Pellegrina, Diogo et al. "Septic Shock in Advanced Age: Transcriptome Analysis Reveals Altered Molecular Signatures in Neutrophil Granulocytes." Ed. Cordula M. Stover. PLoS ONE 10.6 (2015): e0128341. PMC. Web. 6 July 2015.

A partir deste artigo foi também publicado na revista Genomics Data um "Data in Brief" descrevendo mais aprofundadamente o tratamento de dados.

- Pellegrina, Diogo et al. Microarray gene expression analysis of neutrophils from elderly septic patients, Genomics Data, Volume 6, December 2015, Pages 51-53, ISSN 2213-5960, http://dx.doi.org/10.1016/j.gdata.2015.08.013.

Um terceiro artigo está sendo redigido para publicação tratando da segunda parte deste trabalho, envolvendo os RNAs não codificadores longos e redes de coexpressão. 


\section{Referências}

Attali, B., G. Romey, et al. (1992). "Cloning, functional expression, and regulation of two K+ channels in human T lymphocytes." The Journal of biological chemistry 267(12): 86508657.

Berger, J. A., S. Hautaniemi, et al. (2004). "Optimized LOWESS normalization parameter selection for DNA microarray data." Bmc Bioinformatics 5.

Boehmer, E. D., J. Goral, et al. (2004). "Age-dependent decrease in Toll-like receptor 4-mediated proinflammatory cytokine production and mitogen-activated protein kinase expression." $\underline{\mathrm{J}}$ Leukoc Biol 75(2): 342-349.

Brubaker, A. L., J. L. Rendon, et al. (2013). "Reduced neutrophil chemotaxis and infiltration contributes to delayed resolution of cutaneous wound infection with advanced age." $\underline{\mathrm{J}}$ Immunol 190(4): 1746-1757.

Cabili, M. N., C. Trapnell, et al. (2011). "Integrative annotation of human large intergenic noncoding RNAs reveals global properties and specific subclasses." Genes \& Development 25(18): 1915-1927.

Cevenini, E., D. Monti, et al. (2013). "Inflamm-ageing." Curr Opin Clin Nutr Metab Care 16(1): 1420.

De Gaudio, A. R., S. Rinaldi, et al. (2009). "Pathophysiology of sepsis in the elderly: clinical impact and therapeutic considerations." Curr Drug Targets 10(1): 60-70.

Fagiolo, U., A. Cossarizza, et al. (1993). "Increased cytokine production in mononuclear cells of healthy elderly people." Eur J Immunol 23(9): 2375-2378.

Fatica, A. and I. Bozzoni (2014). "Long non-coding RNAs: new players in cell differentiation and development." Nature Reviews Genetics 15(1): 7-21.

Franceschi, C., M. Bonafe, et al. (2000). "Human immunosenescence: the prevailing of innate immunity, the failing of clonotypic immunity, and the filling of immunological space." Vaccine 18(16): 1717-1720.

Friedman, J., T. Hastie, et al. (2009). The Elements of Statistical Learning Data Mining, Inference, and Prediction. Springer Series in Statistics, New York, NY, Springer-Verlag New York.

Gentleman, R. C., V. J. Carey, et al. (2004). "Bioconductor: open software development for computational biology and bioinformatics." Genome Biology 5(10).

Gertz, E. M., K. Sengupta, et al. (2009). "Evaluating annotations of an Agilent expression chip suggests that many features cannot be interpreted." Bmc Genomics 10.

Girard, T. D., S. M. Opal, et al. (2005). "Insights into severe sepsis in older patients: from epidemiology to evidence-based management." Clin Infect Dis 40(5): 719-727.

Gomez, J. A., O. L. Wapinski, et al. (2013). "The NeST Long ncRNA Controls Microbial Susceptibility and Epigenetic Activation of the Interferon-gamma Locus." Cell 152(4): 743754.

Grubeck-Loebenstein, B. and G. Wick (2002). "The aging of the immune system." Adv Immunol 80: 243-284.

Harrow, J., A. Frankish, et al. (2012). "GENCODE: The reference human genome annotation for The ENCODE Project." Genome Research 22(9): 1760-1774.

Heppner, H. J., S. Cornel, et al. (2013). "Infections in the elderly." Crit Care Clin 29(3): 757-774.

Hong, F. X., R. Breitling, et al. (2006). "RankProd: a bioconductor package for detecting differentially expressed genes in meta-analysis." Bioinformatics 22(22): 2825-2827.

Howcroft, T. K., J. Campisi, et al. (2013). "The role of inflammation in age-related disease." Aging (Albany NY) 5(1): 84-93.

Huang, D. W., B. T. Sherman, et al. (2009). "Systematic and integrative analysis of large gene lists using DAVID bioinformatics resources." Nature Protocols 4(1): 44-57.

Iskander, K. N., M. F. Osuchowski, et al. (2013). "Sepsis: multiple abnormalities, heterogeneous responses, and evolving understanding." Physiol Rev 93(3): 1247-1288. 
Kadota, K., Y. Nakai, et al. (2009). "Ranking differentially expressed genes from Affymetrix gene expression data: methods with reproducibility, sensitivity, and specificity." Algorithms for Molecular Biology 4.

Kale, S., S. Yende, et al. (2010). "The effects of age on inflammatory and coagulation-fibrinolysis response in patients hospitalized for pneumonia." PLoS One 5(11): e13852.

Kale, S. S. and S. Yende (2011). "Effects of Aging on Inflammation and Hemostasis through the Continuum of Critical Illness." Aging Dis 2(6): 501-511.

Kelly, E., R. E. MacRedmond, et al. (2009). "Community-acquired pneumonia in older patients: does age influence systemic cytokine levels in community-acquired pneumonia?" Respirology 14(2): 210-216.

Kent, W. J., C. W. Sugnet, et al. (2002). "The human genome browser at UCSC." Genome Research 12(6): 996-1006.

Kovach, M. A. and T. J. Standiford (2012). "The function of neutrophils in sepsis." Current Opinion in Infectious Diseases 25(3): 321-327.

Langfelder, P. and S. Horvath (2008). "WGCNA: an R package for weighted correlation network analysis." Bmc Bioinformatics 9.

Legendre, P. and L. Legendre (1998). Numerical ecology. Amsterdam ; New York, Elsevier.

Li, N., Y. Zhai, et al. (2015). "Structure of the eukaryotic MCM complex at 3.8 A." Nature 524(7564): 186-191.

Liao, Q., C. N. Liu, et al. (2011). "Large-scale prediction of long non-coding RNA functions in a coding-non-coding gene co-expression network." Nucleic Acids Research 39(9): 38643878.

Mari, D., P. M. Mannucci, et al. (1995). "Hypercoagulability in centenarians: the paradox of successful aging." Blood 85(11): 3144-3149.

Mascarucci, P., D. Taub, et al. (2001). "Age-related changes in cytokine production by leukocytes in rhesus monkeys." Aging (Milano) 13(2): 85-94.

Nasa, P., D. Juneja, et al. (2012). "Severe sepsis and septic shock in the elderly: An overview." World J Crit Care Med 1(1): 23-30.

Opal, S. M., T. D. Girard, et al. (2005). "The immunopathogenesis of sepsis in elderly patients." Clin Infect Dis 41 Suppl 7: S504-512.

Pagani, M., G. Rossetti, et al. (2013). "Role of microRNAs and long-non-coding RNAs in CD4+Tcell differentiation." Immunological Reviews 253: 82-96.

Peixoto, B. R., R. Z. N. Vencio, et al. (2006). "Evaluation of reference-based two-color methods for measurement of gene expression ratios using spotted cDNA microarrays." Bmc Genomics 7.

Pellegrina, D. V., P. Severino, et al. (2015). "Microarray gene expression analysis of neutrophils from elderly septic patients." Genom Data 6: 51-53.

Peng, X. X., L. Gralinski, et al. (2010). "Unique Signatures of Long Noncoding RNA Expression in Response to Virus Infection and Altered Innate Immune Signaling." Mbio 1(5).

Pinheiro da Silva, F., F. G. Zampieri, et al. (2013). "Septic shock in older people: a prospective cohort study." Immun Ageing 10(1): 21.

Plackett, T. P., E. D. Boehmer, et al. (2004). "Aging and innate immune cells." J Leukoc Biol 76(2): 291-299.

Plackett, T. P., E. M. Schilling, et al. (2003). "Aging enhances lymphocyte cytokine defects after injury." FASEB J 17(6): 688-689.

Renshaw, M., J. Rockwell, et al. (2002). "Cutting edge: impaired Toll-like receptor expression and function in aging." $\mathrm{J}$ Immunol 169(9): 4697-4701.

Shinkai, S., M. Konishi, et al. (1998). "Aging and immune response to exercise." Can J Physiol Pharmacol 76(5): 562-572.

Starr, M. E. and H. Saito (2014). "Sepsis in old age: review of human and animal studies." Aging Dis 5(2): 126-136. 
Tateda, K., T. Matsumoto, et al. (1996). "Lipopolysaccharide-induced lethality and cytokine production in aged mice." Infect Immun 64(3): 769-774.

Turnbull, I. R., J. J. Wlzorek, et al. (2003). "Effects of age on mortality and antibiotic efficacy in cecal ligation and puncture." Shock 19(4): 310-313.

Tusher, V. G., R. Tibshirani, et al. (2001). "Significance analysis of microarrays applied to the ionizing radiation response." Proc Natl Acad Sci U S A 98(9): 5116-5121.

Volders, P. J., K. Helsens, et al. (2013). "LNCipedia: a database for annotated human IncRNA transcript sequences and structures." Nucleic Acids Research 41(D1): D246-D251.

Weksler, M. E., M. Goodhardt, et al. (2002). "The effect of age on B cell development and humoral immunity." Springer Semin Immunopathol 24(1): 35-52.

Wu, Y. T., C. Huang, et al. (2015). "Long Noncoding RNA MALAT1: Insights into its Biogenesis and Implications in Human Disease." Current Pharmaceutical Design 21(34): 5017-5028.

Xie, C. Y., J. Yuan, et al. (2014). "NONCODEv4: exploring the world of long non-coding RNA genes." Nucleic Acids Research 42(D1): D98-D103.

Yue, D., H. Liu, et al. (2009). "Survey of Computational Algorithms for MicroRNA Target Prediction." Current Genomics 10(7): 478-492.

Zhang, B. and S. Horvath (2005). "A general framework for weighted gene co-expression network analysis." Statistical Applications in Genetics and Molecular Biology 4. 